Portland State University

PDXScholar

Fall 12-2-2016

\title{
Citizen-led Urban Agriculture and the Politics of Spatial Reappropriation in Montreal, Quebec
}

Claire Emmanuelle Bach

Portland State University

Follow this and additional works at: https://pdxscholar.library.pdx.edu/open_access_etds

Part of the Urban, Community and Regional Planning Commons, and the Urban Studies Commons Let us know how access to this document benefits you.

\section{Recommended Citation}

Bach, Claire Emmanuelle, "Citizen-led Urban Agriculture and the Politics of Spatial Reappropriation in Montreal, Quebec" (2016). Dissertations and Theses. Paper 3366.

https://doi.org/10.15760/etd.5257

This Thesis is brought to you for free and open access. It has been accepted for inclusion in Dissertations and Theses by an authorized administrator of PDXScholar. Please contact us if we can make this document more accessible: pdxscholar@pdx.edu. 


\title{
Citizen-led Urban Agriculture
}

and the Politics of Spatial Reappropriation in Montreal, Quebec

\section{by}

Claire Emmanuelle Bach

A thesis submitted in partial fulfillment of the requirements for the degree of

\author{
Master of Urban Studies in Urban Studies
}

Thesis Committee:

Nathan McClintock, Chair

Megan Horst

Marisa Zapata

Portland State University 2016 
(C) 2016 Claire Emmanuelle Bach 


\begin{abstract}
Urban Agriculture (UA) has been practiced in Montreal, Quebec for well over a century. In the last five years or so, a renewed enthusiasm for UA has manifested itself in the form of citizen-led UA projects. The latter are often established in residual spaces, from vacant lots to sidewalks, and alleyways. These more spontaneous and informal UA practices point to a shift in how urban inhabitants perceive and use urban space. Through a case study of informal UA projects in Montreal, QC, this work brings attention to the dynamics surrounding the establishment of citizen-led UA projects, paying special attention to their complex structure. Indeed, although they are usually initiated by groups of citizens, other actors are either directly or indirectly involved, including non-profit organizations, municipal officials, or business owners. To better understand these processes, I ask the following questions:
\end{abstract}

- Why are citizens in Montreal reappropriating vacant and underused urban spaces for UA?

- How are these spaces being established, and who is involved?

- How might these spaces and the social relations forged within them, contributing - or not - to a democratic urban politics?

Bringing together existing scholarship on critical urban agriculture, radical democracy, and urban geography, this research exposes some of the inherent tensions present in contemporary UA. This work demonstrates that collective UA projects exist simultaneously as a political practice, and one that might not significantly alter the existing spatial and social orders. 


\section{Acknowledgements}

This project was funded by a Québec/United States University Grant Program Major Academic Initiative grant from the Government of Québec's Ministry of International Relations and La Francophonie. I would like to thank my advisor, Nathan McClintock, for guiding me throughout my Masters studies and providing helpful feedback on my work. Thanks also to committee members Marisa Zapata and Megan Horst for their comments. I am grateful to Éric Duchemin for recommending interview participants in Montreal, as well as to all of the Urban Agriculture practitioners and city officials I've had the chance to interview. Merci Matos for being a great host in Montreal while I was conducting my research. I would also like to thank my parents Raymond and Sylvie Bach for their continued support and patience, as well as my aunt Claudia for giving me good advice. Thank you to my Grand-mère and Grand-père who have always been there for me. Finally, I would like to thank my friends near and far, Marcus (Dji), Nathan, Alicia, Kathryn and Robert, thank you for encouraging me to be my best. 


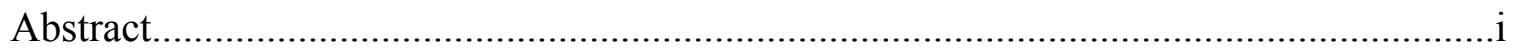

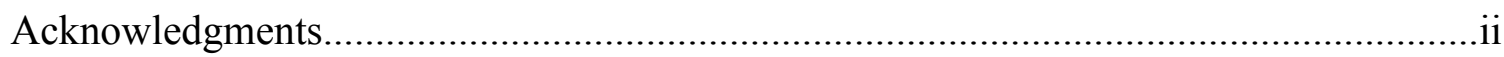

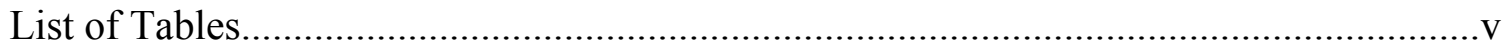

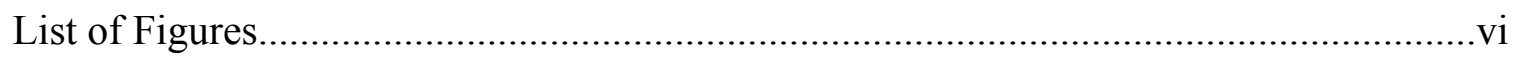

Section I.

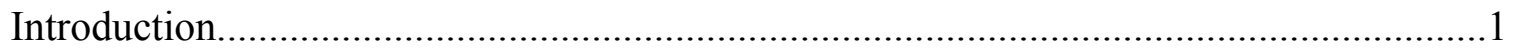

Section II

Theoretical Framework: Citizen-Projects and the Collective Transformation of Urban

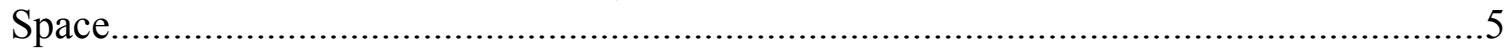

Critical Urban Agriculture............................................................................ 5

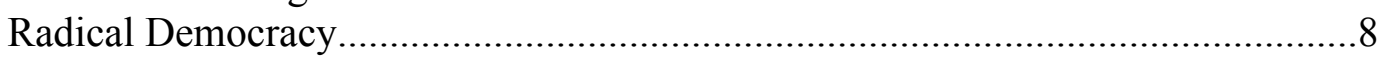

Spatializing the Political...........................................................................11

Destabilizing the Existing Spatial Order..........................................................15

Section III.

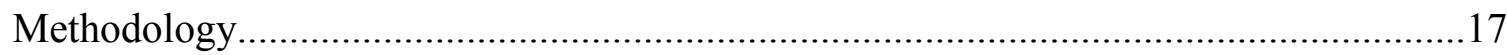

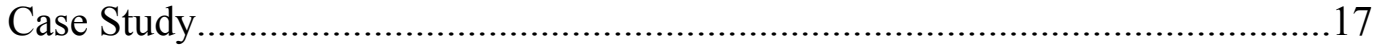

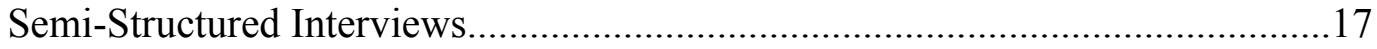

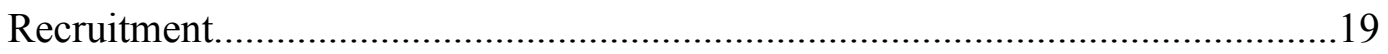

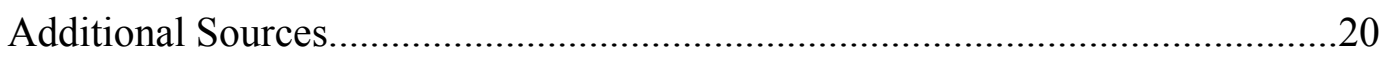

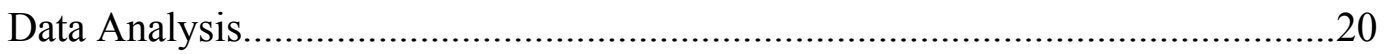

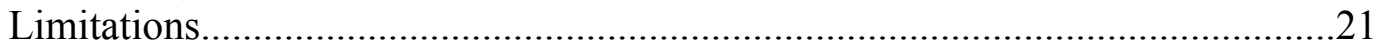

Section IV.

UA in Montreal: Historical roots and current trajectory.............................................23

Historical Roots of UA in Montreal...............................................................23

Institutionalizing UA: Montreal's Community Garden Program..........................24

From Community to Collective Gardens..........................................................26

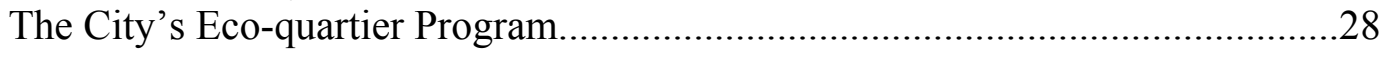

Citizen-Led UA Projects.............................................................................29

Towards a Comprehensive UA plan: Montreal's Public Consultation.............30

Section V.

Findings: Understanding the dynamics of citizen projects in UA.................................33

1. Why are vacant and underused spaces being reappropriated for UA?..........33

Limitations of Existing UA Infrastructure..............................................33

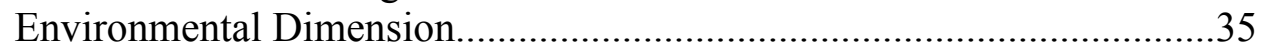

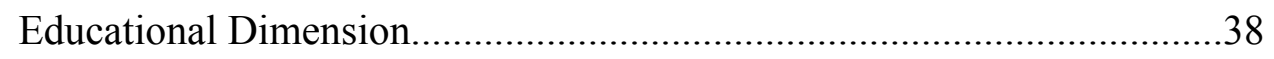




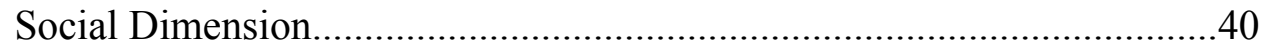

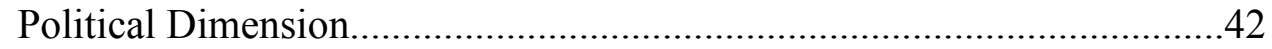

Making Food Free to All.................................................................45

2. How are citizen-projects being established?........................................4 47

Community Members Taking Initiative...........................................48

The Involvement of the City..................................................................50

The Push from Boroughs......................................................................5

Working with Public Agencies............................................................55

Citizen-Projects Embedded Within an Organization..............................57

Support from Non-Profit Organizations.............................................58

Section VI.

Discussion: The Production of Collective Spaces and Social Relationships....................62

Transforming Residual Urban Spaces as Political Practice..............................62

Fostering Collective Social Relations............................................................64

Section VII.

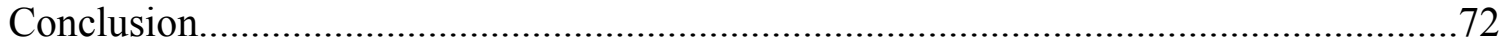

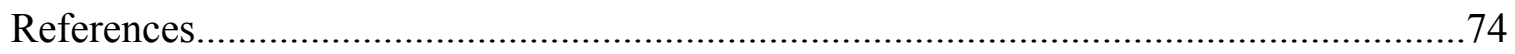

Appendices

A. Interview Guide for UA practitioners (August 2015).................................78

B. Interview Guide for Municipal Officials (April 2016).................................79

C. Additional Interviews from MTL-PDX Field Course....................................80

D. Examples of Codes Employed to Analyze Interview Data.............................81 


\section{List of Tables}

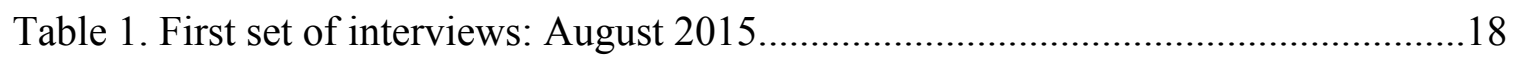

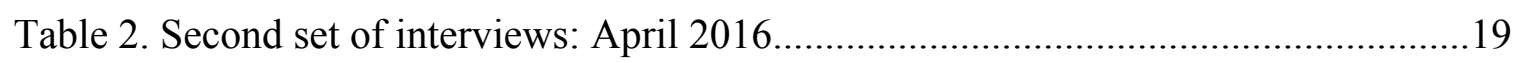




\section{List of Figures}

Figure 1. Le Jardin du Marché.....................................................................................

Figure 2. The Multifunctionality of Urban Agriculture................................................

Figure 3. Map of Citizen Projects Studied........................................................................ 18

Figure 4. The CHAPEAU's 'Plant Everywhere' Initiative...........................................43

Figure 5. Invitation to Participate at the Jardin Pour Tous...........................................66 


\section{Section I. Introduction}

In a vacant lot across the street from Montreal's famous Jean Talon Market, one can find a number of raised garden beds made out of wood and repurposed plastic containers. Two of the raised beds read in large painted letters: 'Cultivons l'espace', which in French means 'cultivate space' (Figure 1). This garden is just one among many in the city of Montreal, where informal, community-led urban agriculture (UA) projects have emerged in underused and vacant spaces. These 'citizens projects' (projets citoyens) have gained recognition over the last few years, prompting some boroughs to implement new policies regarding citizen reappropriation of vacant and underused spaces. Additionally, non-profit organizations are increasingly accompanying citizens to help their projects take off. ${ }^{1}$

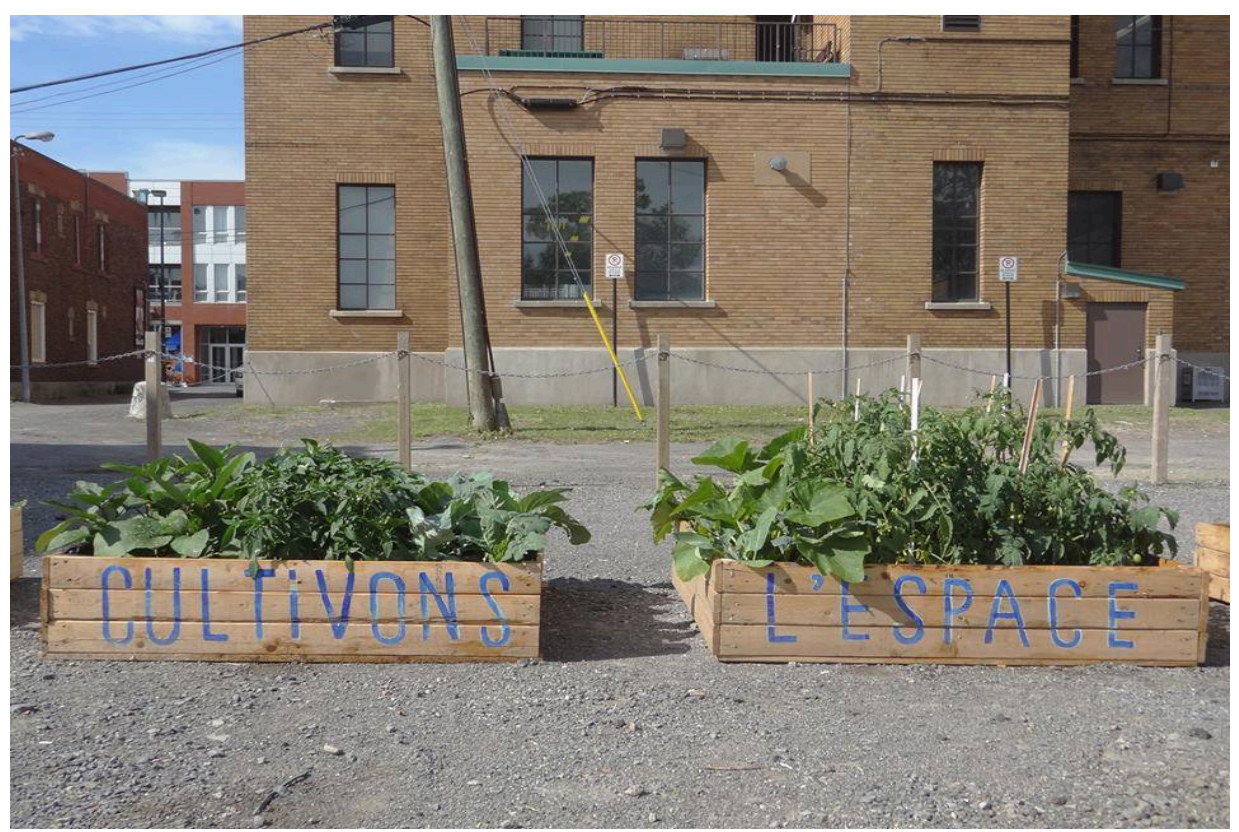

Figure 1. Le Jardin du Marché

\footnotetext{
${ }^{1}$ In French, the term 'citizen' (citoyen) is not necessarily connected to national citizenship; rather in this context, it is more closely associated with civic identity and the urban inhabitant. I will therefore refer to these projects interchangeably as 'citizen projects' or 'community-led projects' to stay close to the French term.
} 
The proliferation of citizen UA projects can be situated within a broader resurgence of UA in North American cities and in the Global North more generally, which has been underway since the early 2000s (Tornaghi 2014). Before delving into the significance of these practices for the city and its inhabitants, it is worth briefly looking back at the historical roots of UA in North America. In the early to mid $20^{\text {th }}$ century, UA was widely practiced by the working class as a means for food security and selfsufficiency. These practices were encouraged by national governments during times of war and economic crisis, with the objective of responding to food shortages caused by the shrinking agricultural labor force (Saint-Hilaire-Gravel, 2013). In addition to physical sustenance, the Victory Gardens were also intended to boost morale. Large public spaces, usually parks, were converted into garden plots where families tended to their personal gardens. The production in Victory Gardens was highly intensive and amounted to $40 \%$ of all vegetables grown in the entire United States in 1944 (National WWII Museum). After World War II, urban food production declined sharply, as a new era of prosperity and consumerism pervaded in the Western world. With the energy crisis of the 1970's, people began questioning the existing political-economic system, as the environmental movement took shape. During this era, community gardens became popularized in urban centers throughout North America, with more or less support from municipalities. Often under the tutelage of Parks and Recreation departments, gardening retained a primarily recreational vocation (Massé and Beaudry, 2008).

In Montreal, Quebec, UA has been practiced for well over a century, predominantly during periods of social and economic unrest. In the mid- $20^{\text {th }}$ century, UA 
was therefore primarily a strategy for food provisioning, as well as a way for immigrants from southwestern Europe - primarily Italy and Portugal - to obtain culturally appropriate foods. In the 1960s and 1970s, the city's municipal community garden program popularized UA as a leisure activity. The 1990s saw the rise of collective gardens run by non-profit organizations, addressing underlying socio-economic disparities. Yet, the more spontaneous and informal UA practices emerging today point to an important shift in UA, one I argue exhibits a collective ethos and a larger reconceptualization of how urban space should be used, and by whom.

Focusing on these emerging UA practices, this research strives to uncover what motivates people to transform these spaces. Through a case study of community-led UA projects in Montreal, QC, this work brings attention to the dynamics surrounding the establishment of these gardens, specifically to their complex and interrelated nature. Indeed, although these gardens are usually initiated by groups of citizens, other actors are either directly or indirectly involved, including non-profit organizations, municipal officials, or business owners. To better understand these processes, my first research question asks: Why are citizens reappropriating particular urban spaces for UA? I begin by looking at some of the common motivations of gardeners across several citizen projects. Although food production is a major incentive for participants, I suggest that other interests often spur these practices, such as a desire for greater social interaction, or to feel more connected to one's environment. After looking at why these practices are emerging, I turn to asking: How are these spaces being established? In other words, which actors - if any - are supporting or assisting citizen groups in their endeavors? Bringing together current literature on critical urban agriculture, radical democracy, and 
urban geography, I then turn to a more theoretically grounded discussion around the significance of these spatial practices in fostering a democratic urban politics. My third research question therefore asks: How might these spaces and accompanying social relations contribute to a democratic urban politics? Though not systematically, existing scholarship on UA often tends to fall into dichotomies, on the one hand rendering UA practices unproblematic and inherently 'good' for people and places, and on the other hand casting UA as simply another tool of for capitalist urbanization. Following McClintock (2014), Classens (2015), and others, this research examines how these contradictions play out in the context of civic-led UA projects in Montreal, and how these initiatives exist simultaneously as a deeply political practice, and one that might also appear to reside outside the realm of politics. 


\section{Section II. Theoretical Framework: \\ Citizen-UA Projects and the Collective Transformation of Urban Space}

\section{Critical Urban Agriculture}

Geographers, sociologists, and food scholars are bringing increasing focus to a new wave of urban agriculture (UA) in North American cities, and in the Global North more generally (Eizenberg 2012; McClintock 2014; Tornaghi 2014). While urban food production is by no means a new phenomenon, UA is increasingly being understood as a multifunctional practice (Figure 2), able to contribute - among other things - to public health, education, social integration or economic development (Duchemin et al. 2008). Furthermore, the range of UA practices has moved beyond simple horticulture, to encompass practices as diverse as beekeeping collectives, commercial hydroponic rooftop farms, or animal husbandry.

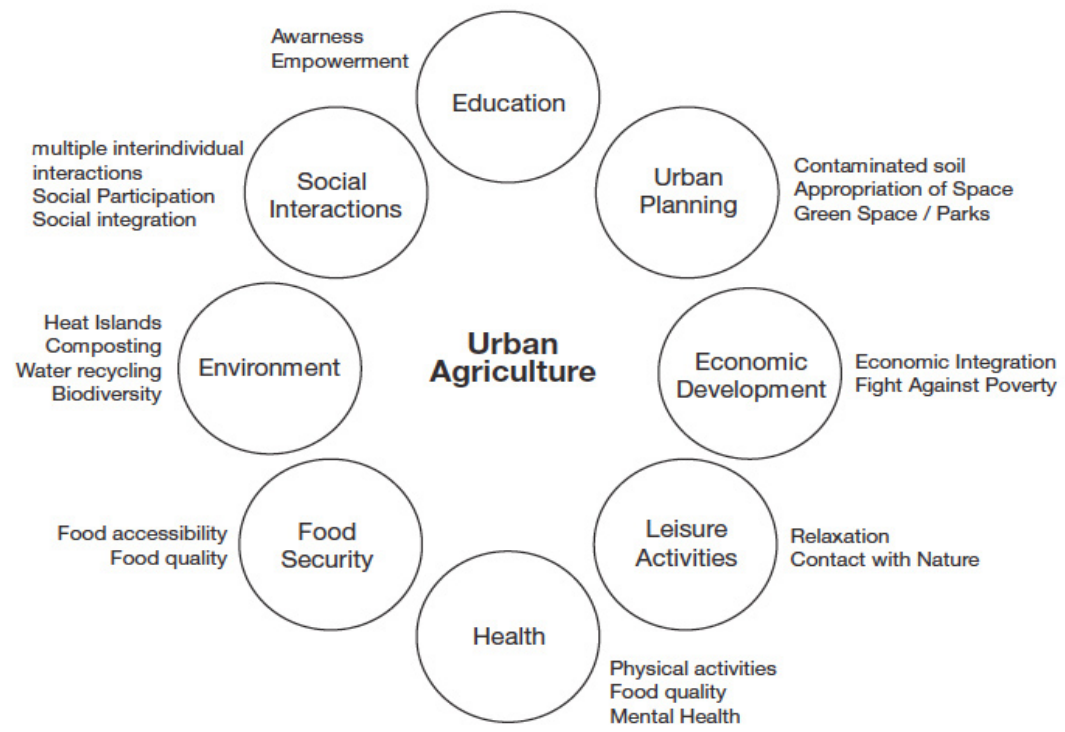

Figure 2. The multifunctionality of UA (Duchemin et al. 2008) 
The current resurgence of UA can be situated within the larger Alternative Food Movement (AFM). At its core, the AFM seeks to oppose and build alternatives to the global corporate food system. It stems from a broader recognition that the current food system rests on social, environmental, and economic injustices and that it is possible to create just and sustainable alternatives. Given the breadth of the initiatives under the AFM umbrella, in-depth treatment of these topics is impossible; still, it is worth mentioning that the proliferation of alternatives has developed at every echelon of the food system, from farm worker movements for living wages and working conditions, to advocacy for organic and local food production, and the creation of urban gardens as a tool for food justice and food sovereignty.

Yet, while all these movements might find themselves under the AFM banner, it is worth noting that initiatives range from radical to progressive, as well as thoroughly apolitical. The main critique voiced by geographers and food scholars has been the fact that many of these so-called 'alternative' food movements actually tend to reproduce the inequalities of the dominant food system, by failing to engage with systemic issues. Scholars and practitioners alike have frequently discussed how these tensions play out in the realm of UA. Some scholars have focused disproportionately on the positive outcomes of UA (see Figure 2), casting it as an inherently 'good' and unproblematic practice. Yet, others have warned against the romanticization of UA, insofar as it risks glossing over the power imbalances and social inequalities that are often reproduced within UA initiatives. As Tornaghi $(2014,553)$ explains, "we need to scrutinize more closely the way these initiatives are becoming directly or indirectly, new tools or justification for a new wave of capital accumulation (...), economic-growth-led policies 
(..), privatization of the urban realm (...), and disinvestments in disadvantaged neighborhoods..." In this sense, some critics have rejected UA's radical potential, casting it as just another tool for capitalist urbanization (Perkins 2009; Rosol 2012).

Still, others have argued that falling into this dichotomous debate does not in fact lead to a better understanding of UA, and that a more nuanced approach must be taken instead (McClintock 2014, Classens 2015). From this perspective, UA is understood as a paradoxical practice that exists simultaneously as a node of resistance to capitalist urbanization and an inevitable element of this very same hegemonic system. UA is thus constituted by "contradictory processes (...) that both create opportunities for urban agriculture and impose obstacles to its expansion" (McClintock 2014, 157). These processes, far from being homogenous and fixed, are always-already fluid and influenced by history, place, and scale. In this sense, it is important to recognize the dialectical relationship between UA practices and the social, political, and economic contexts within which they develop.

Despite being simultaneously radical, reformist, and "garden-variety neoliberal" (McClintock 2014), many see UA as an 'insurgent practice' or 'political act' (Tornaghi and Van Dyck 2015) capable of destabilizing - if ever so slightly - the capitalist organization of space and the social relations within it. In this sense, a portion of critical UA literature has focused on UA as a potential vehicle for developing an urban democratic politics, through the redefinition of everyday socio-natural interactions (Levkoe 2011, Eizenberg 2012, Classens 2015). Many have pointed out that it is precisely the nature of these macro-spatial transformations that opens up possibilities for alternatives and broader social change (Iveson, 2013). My own work sits within these 
debates, and seeks to "interrogate [these initiatives] as forms of political agency that contest, transform and re-signify "the urban"” (Tornaghi 2015, 1123). As we will see, these initiatives are not always explicitly political, yet the material transformation of space, and the symbolism that comes with it, suggests that these actions do in fact hold within them the potential to redefine spaces and the social relations. As Tornaghi (2015, 1126) explains, "the radical meaning [of UA initiatives] does not always take shape through radical actions." In this sense, we should not restrict the transformative potential of initiatives to a specific form of UA that might be found 'outside' the arena of community organizations or even municipal programs.

The proliferation of citizen UA projects can be situated within a larger shift towards a more collective management of urban spaces. Keeping in mind that these projects are neither completely 'radical' nor 'reformist' (McClintock 2014), I suggest that these practices have important ramifications for how we conceive of democracy, space, and politics, and specifically about the relationship between politics and the transformation of material spaces. In order to interrogate the political and democratic contours of collective UA initiatives and to better understand if and how these projects might embody a radical democratic politics, I turn to debates within radical democracy and critical urban theory.

\section{Radical Democracy}

The concept of radical democracy stands it stark contrast with conventional notions of democracy, usually understood as the institutions, elections, and structures that make up our political system. For Purcell (2013), and others before him, this kind of 
democracy - liberal or representative democracy - is essentially an oxymoron. Insofar as representative democracy involves the rule of the people by a handful of elected officials, it stands at odds with actual democracy, defined by Purcell $(2013,20)$ as "a way of living together in which people rule themselves." Radical democracy thus involves a level of autonomy that is antithetical to representative democracy. It requires people to become active in shaping their own lives. In his work The Hatred of Democracy (2005), Rancière writes (60): "Representation is in its very nature, the exact opposite of democracy."

Furthermore, radical democracy brings attention to the fundamentally dynamic nature of democracy. It is not, as we might think, an absolute end-state of political stability, but rather an ongoing process, a struggle that must continually renew itself. A democratic society is therefore not an end point, but rather a horizon that must be collectively worked towards (Purcell 2013). Drawing from Hardt and Negri (2000), Purcell suggests that a central tenet of this struggle is the reappropriation of people's immanent, or constituent power. In short, constituent power refers to a popular power that arises from below, that "originates in the bodies of the multitude" (Purcell 2013, 13). Most of the time, people are unaware of the power they hold. This is because much of it has been consolidated by the State into 'constitutive power' (Hardt and Negri 2000 in Purcell 2013). While Purcell uses these specific terms, philosophers as far back as Aristotle and Nietzsche have grappled with these very ideas. Ultimately, the power of the State, or of any politicaleconomic system, essentially depends on the immanent power of individuals, and the subsequent amalgamation of their power. Yet constitutive power must also continually legitimize itself by portraying constituent power as weak, fleeting and insignificant. Thus an iterative process is at work, whereby the individual conceives of him/herself as 
essentially powerless, which further strengthens constitutive power as the only real or legitimate form of power. The process of reappropriating one's power represents an act of resistance to hegemonic power structures.

Similarly for Rancière, radical democracy is both an individual and collective project. It is at its core, resistance to constitutive and disciplinary power, a continual disruption of the existing social order. He refers to this social order as 'the police', which encompasses a "set of procedures, whereby power is institutionalized, places and roles in society are distributed, and the entirety of the system is legitimized" (Purcell 2013, 66). In this sense, the entire social order rests on divisions and hierarchies, what Rancière refers to as the partage du sensible, the 'partition of the sensible. ${ }^{2}$ While this partage $d u$ sensible rests on false differentiations, it has very tangible consequences. In fact, "it defines what is visible and what is sayable, what bodies can be seen and what voices can be understood" (Purcell 2013, 66). Ultimately, for Rancière, the task of radical democracy - or politics is to make visible the contingent nature of these relationships and hierarchies, to show that no social order is natural and pre-determined.

To further these ideas, Rancière employs the notion of 'original equality'. Original equality assumes that because we are all capable of logos (i.e., we all have language and reason), we are also capable of ruling ourselves, of managing our own lives. This does not mean that anyone can do anything, or that we are all bestowed with the same skills and knowledge, "but rather than we must presume the equal ability of all to learn and, by extension, the equal ability to govern, adjudicate and mediate" (Davidson

\footnotetext{
${ }^{2}$ In French, the word sensible has different meanings not captured by the English word. The French term can signify what is sensible, the sensitive, and that which can be sensed. Here, the latter is most closely related to Rancière's use of the term.
} 
and Iveson 2014,13). To make his claim for an original equality, Rancière draws from Plato and Aristotle. For Aristotle, the master has logos but the slave does not. This hinges on a major contradiction, because without logos, the slave would not comprehend the master's orders. In this sense, "Rancière sees irrefutable evidence of the contingent and constructed nature of all social orders" (Purcell 2013, 68). What is needed, then, is the continual disruption of the police order through what Rancière terms 're-inscriptions' of equality in the social world. What does this look like practically? How do disruptions occur and just as importantly where do they happen?

\section{Spatializing the Political}

All disruptions and radical democratic politics necessarily happen in geographical space. Rancière did not dwell on the spatial dimension of politics, though it often appears in his work implicitly. As Davidson and Iveson $(2014,145)$ point out, "politics as understood by Rancière can potentially occur in any space. It is not the inherent qualities of a given space that makes it political or not, but rather the way in which it is mobilized. No particular kind of place is proper to politics." In this sense, space becomes a tool albeit an essential one - for the political to emerge. Similarly for Purcell, and Lefebvre before him, space is at the center of any political project. As Purcell clearly puts it (2013, 90), "democracy must involve not just the reappropriation of our power but also the reappropriation of our space."

Lefebvre's theory of space is helpful in that it extends Rancière's argument. For Lefebvre, space is not a given entity, but is instead complex and dynamic. There is no single way to use space, much less one way to perceive it; there are instead myriad 
possibilities. At the heart of Lefebvre's theory of space is a distinction between abstract space and differential space. The former, also referred to as 'conceived' space, bears much resemblance to Rancière's police, to the established social order. Abstract space is ubiquitous, insofar as it is the space determined by planners, architects, and other experts; yet these spaces often develop with the underlying aim of controlling how people use it. This kind of restriction of movement and action occurs in very subtle ways, such as the placement of armrests on benches to keep people from sleeping on them. As Merrifield (2006, 112) explains, "within abstract space, are subtle ideological and political machinations, which maintain a perpetual dialogue between its space and users, prompting compliance and 'nonaggression' pacts (...) Abstract space impregnates people, socializes everybody as spatial bodies and class subjects." Therefore, abstract space, similarly to Rancière's social order, circumscribes the way spaces can be used and creates its own set of hierarchies.

But abstract space cannot contain the actual practices and uses of space, what Lefebvre refers to as the lived and perceived dimensions of differential space. Within differential space, Rancière's police order is turned on its head, as people become aware of their ability to transform and produce new kinds of spaces. It is in this sense that Lefebvre speaks of the city as an 'oeuvre', as a process of creative production in which all people, regardless of their place in the social order, are equally capable of producing urban space. Thus, differential space operates dialectically, and opens up the possibility of transforming relations of competition and domination into relations of "encounter, cooperation, [and] self-realization" (Purcell 2013, 83) This was indeed Lefebvre's long- 
term vision, as he conceptualized an urban society built around values of 'autogestion' (self-management) and mutual aid. This does not mean, however, that we can do away with abstract space completely. It continues to shape cities and, like the police, orders the social relationships within it. Yet it is possible to disrupt these spaces and their original functions, to (re)appropriate them for radically different ends.

Lefebvre sees this creative process as contributing to the 'oeuvre' of the city. The 'oeuvre' for Lefebvre, "is use value and the product is exchange value. The eminent use of the city, that is, of its streets and squares, building and monuments, is la fête (which consumes unproductively, without any other advantage than pleasure and prestige" (Merrifield 2006, 69). Purcell reminds us that this vision of urban society is not entirely unachievable, but must rather be conceived of as a horizon to be worked towards. In this creative process we can recognize Rancière's conception of the political, as people push back against abstract space and the existing social order. Similarly to Rancière, Lefebvre sees potential for transformation in any space of the city. Furthermore, he sees this as an inherent right to participation. Indeed, his 'right to the city' is first and foremost a right to create urban space, a "right to urban life" itself (Lefebvre 1968, 158). From this standpoint, the individual becomes a creative force, as opposed to a passive and inert subject. Any space is therefore apt to house the political. Beyond larger social movements and uprisings, a radical democratic politics can manifest itself in everyday creative actions within space.

Ultimately, it is the amalgamation of these political practices that holds emancipatory potential. Swyngedouw echoes this view when he claims that politics is a performative staging of equality (Swyngedouw 2014, 132): "without a site, a place or a 
location, a political idea is impotent." The political is thus in itself "a site open for occupation by those who call it into being, render it visible, and stage its occupation, irrespective of the 'place' they occupy within the social edifice" (Swyngedouw 2014, 123). In this sense, the occupation and use of space has the potential to destabilize hierarchies, and foster instead a collective being-together. From Rancière's perspective, a radical democratic politics will always end up being reintegrated within the dominant social order. Therefore, the political is always a temporary moment that cannot be consolidated into a permanent state of radical democracy. This brings us back to Purcell's understanding of radical democracy as a horizon at which one can never totally arrive.

Critical geographers and political theorists have been drawing attention to the 'post-political' or 'post-democratic' nature of urban governance. As Swyngedouw (2011) claims, a form of blanket consensus has been established, foreclosing a democratic politics. In this sense, cities are increasingly being managed according to 'technocratic' knowledge. The concept of 'sustainability' exemplifies how this de-politicization has taken over, insofar as everybody agrees that sustainability is fundamentally 'good' and inherently desirable for all. A consensual post-politics is evident in the context of sustainability, which is best reflected in Swyngedouw's assertion: "I have not been able to find a single source that is against "sustainability" (Swyngedouw 2007, 20). Sustainability puts forth a one-dimensional Nature that is highly symbolic, thereby foreclosing the existence of different, and contingent natures. It further conceals the ways in which Nature is shaped by dominant and hegemonic political processes. Indeed, "sustainability as a goal in itself (...) is the preservation of the status quo" (Davidson 2009, 609). As a whole, this de-politicized form of urban politics is problematic because 
it provides a one-dimensional, 'rational' course of action, and a simplification of environmental, social, and political issues. This de-politicization further forecloses conflict and disagreement, which are the foundation of a democratic politics, and perpetuates uneven power relations.

\section{Destabilizing the Existing Spatial Order}

The reappropriation of urban spaces for UA points to a fundamental shift in how urban space is conceptualized by its everyday users. While the private and public binary still very much determines the way space is used in the neoliberal city, there is an increasing tendency on the part of ordinary citizens to view urban space "as a resource that belongs to everybody and to nobody at the same time" (Corcoran and Kettle 2015, 1219). These changes expose the contingent nature of the ownership and property model, a model that continues to "present property as fixed, natural, and objective" (Blomley $2003,5)$ Thus, urban space and the claims made over it, are not determined a priori by an objective set of laws, but are instead determined by and produced through social relations. In Unsettling the City (2003), Nick Blomley excavates the multiplicity of perceptions, meanings, and organizations of space, which are rendered invisible by the dominant ownership model. While the spatial order of the ownership model remains hegemonic, alternative uses of space such as those created by community-led UA projects, challenge conventional notions of property. Furthermore, beyond recognition, it can encourage us to enact a system that "recognize[s] other spaces and other modalities of property" (Blomley 2003, 137). 
Collective claims to land are just one of these different modalities of property, ones that are becoming more prevalent, yet remain marginal and subsumed by the dominant ownership and property models. Therefore, emerging collective UA projects must strategically navigate and renegotiate these existing claims to urban space firsthand (Eizenberg, 2012). While people are making different claims to land - whether implicitly or explicitly - there seems to be a growing understanding amongst citizens that urban space is theirs to use and transform. As Eizenberg $(2012,768)$ explains, "the very idea of communal authority of space challenges contemporary common sense." This, in turn, further disrupts the spatial order. In Montreal, there is a growing awareness that these alternative claims to space are not only possible, but also legitimate. Organized, community-led UA projects in vacant and underused spaces have demonstrated that residents have the knowledge and ability to transform neglected spaces in ways that can benefit them and their neighbors. In this sense, the transformation of urban spaces is no longer limited to experts and professionals. However, differences in power and social standing still impact who is able to participate, something I will discuss below. 


\section{Section III. Methodology}

This qualitative research uses ethnographic methods of interviewing and participant observation. I situate this study within a historical and geographical context, so as to better understand the impetus for the development of community-led UA projects. My three main research questions are as follows:

- Why are citizens in Montreal reappropriating vacant and underused urban spaces for UA?

- How are these spaces being established, and who is involved?

- How might these spaces and the social relations forged within them contribute - or not - to a democratic urban politics?

Rather than providing an in-depth analysis of community-led UA projects in Montreal, my intention is to identify common themes around the establishment and dynamics of these emerging spaces. I chose to look simultaneously at several citizen initiatives and grassroots organizations. The disproportionate focus on one borough, Rosemont-La Petite-Patrie, reflects the fact that UA and the reappropriation of space are a central concern in this borough, both for residents and municipal officials.

\section{Semi-structured interviews}

This work draws first and foremost from twelve semi-structured interviews (see Appendices A and B for interview guides). Six of these interviews were conducted in August 2015 (see Table 1) and six more in April 2016 (see Table 2) in Montreal, Quebec, Canada. During the first round of interviews, I spoke primarily with people directly engaged in community-led UA projects. This first stage of interviewing led me to better 
understand the dynamics behind the formation of these initiatives, and the involvement of other actors at different levels of governance.

Table 1. First set of interviews: August 2015

\begin{tabular}{ll}
\hline Name & UA Organization or Initiative (Borough) \\
\hline Richard Archambault & Le Mange-Trottoir (Villeray) \\
Nicolas & Le Jardin du Marche (Rosemont-La Petite-Patrie) \\
Richard Bourdeau & Un Jardin Pour Tous (Rosemont-La Petite-Patrie) \\
Catherine Chabot & Le CHAPEAU (Hochelaga Maisonneuve) \\
Stéphane Lavoie & La Maisonette des Parents (Rosemont-La Petite-Patrie) \\
Mikael De Saint-Pierre & La SODER (Rosemont-La Petite-Patrie) / Lande (city-wide) \\
\hline
\end{tabular}

Figure 3 depicts the location of these UA initiatives. This map does not include all of the eighty locations of containers of CHAPEAU, nor does it include the Maisonette des Parents' seventeen collective garden locations. Nevertheless, this map gives us an idea of the hotspots of community-led UA projects in Montreal.

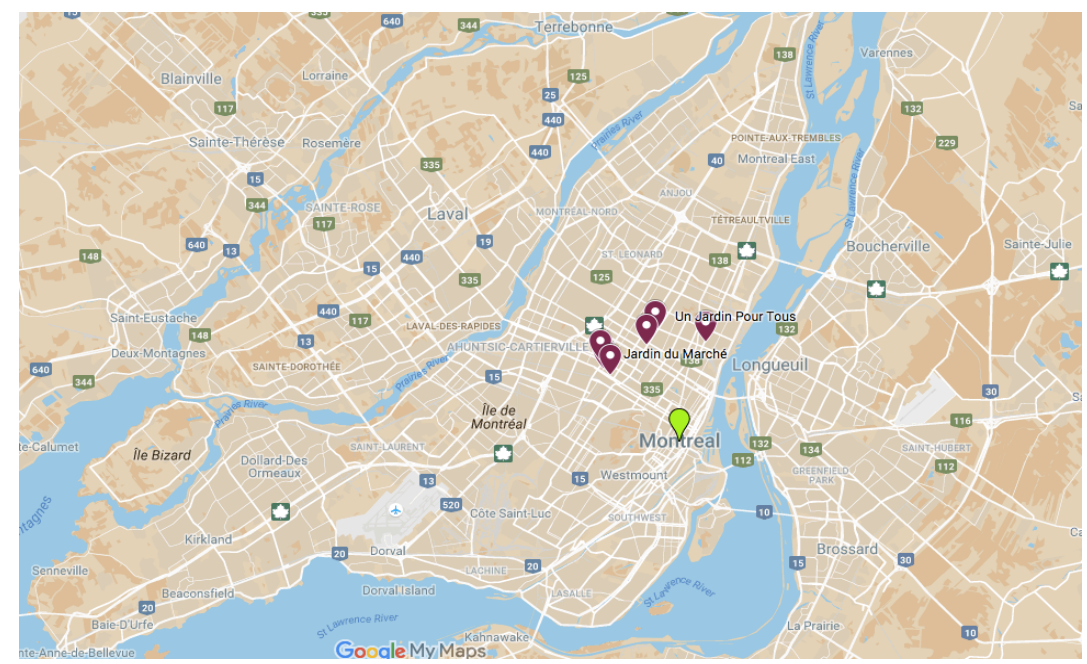

Figure 3. Map of citizen-projects studied in Montreal 
During my second phase of interviews in April 2016, I spoke primarily with municipal officials in order to better understand their perspective on the role of the city vis-à-vis the establishment of these projects. Speaking with city officials from different boroughs, it became clear that the reappropriation of spaces by citizens (for UA or other purposes) is not a concern everywhere, and that it is restricted only to certain parts of the city.

Table 2. Second set of interviews: April 2016

\begin{tabular}{ll}
\hline Name & Organization/ Role at the City (Borough) \\
\hline Jean-Philippe Vermette & Carrefour Alimentaire Centre-Sud (Ville-Marie) \\
Marie-Andrée Mauger & City Councilor (Ville-Marie) \\
Valerie Plante & City Councilor (Verdun) \\
Guillaume Lavoie & City Councilor (Rosemont-La Petite Patrie) \\
Gaëlle Janvier & Alternatives / Lande \\
François Croteau & Mayor (Rosemont-La Petite-Patrie) \\
\hline
\end{tabular}

\section{Recruitment}

Participants were initially identified on-site, during my participation at the $7^{\text {th }}$ Annual Summer School on Urban Agriculture, held from August $10^{\text {th }}$ to August $14^{\text {th }}$, 2015 at the Université du Québec à Montréal (UQAM). This weeklong conference allowed for extensive networking with local UA practitioners. Other participants were further identified using snowball sampling over the course of my 3-week stay in Montreal. Additionally, some participants were identified during the Montreal-Portland UA field course led by Dr. Nathan McClintock and Dr. Éric Duchemin. Dr. Duchemin 
was particularly helpful in suggesting interview participants, both in August 2015 and in April 2016.

\section{Additional sources}

In addition to my own interviews, I drew from interview data gathered during the Montreal-Portland Urban Agriculture field course (see Appendix C) that also took place in August 2015. ${ }^{3}$ My research further draws from newspaper articles, organizational websites and Facebook pages, municipal documents, as well as audio recordings from the radio show 'Montreal Par la Racine' on CIBL 101.5 fm.

\section{Data Analysis}

I coded my interviews using Dedoose qualitative software. Codes were determined in accordance with my three research questions and were sorted in the following categories: "Why are spaces being reappropriated"; "How are spaces being reappropriated"; and finally, "UA as means of producing alternative spaces and social relations." Each question had several sub-codes attached to it, many of which emerged throughout the coding process. For instance, the code "Why are spaces being reappropriated" has several subcodes, including: "alternative to existing UA sites", “environmental mission", and "social mission". This combination of inductive and

\footnotetext{
3 The field course 'Growing Governance: Urban Agriculture Planning, Participation, and Practice in Montreal and Portland' was organized by Dr. Nathan McClintock and Dr. Éric Duchemin in August 2015, during which eight graduate students from the University of Quebec in Montreal and eight from Portland State University conducted interviews with UA practitioners and policy-makers. In Montreal, up to 20 participants were interviewed.
} 
deductive coding was chosen to better identify common themes that cut across different UA projects (see Appendix D for examples of codes).

\section{Limitations}

This research is limited by the fact that I did not live in the site of the study, therefore making a truly ethnographic approach impossible. Indeed, this made it difficult to conduct follow-up interviews and substantial participant observation. Another limitation lies in the geographical reach of this research. A random sampling of projects, organizations, and municipal officials across the city provides an idea of the processes at hand. However, a thorough assessment of a specific borough - perhaps Rosemont-La Petite-Patrie - could have provided a more in-depth analysis of these phenomena. Some of these limitations led me to rework my research questions, as I had originally intended to look at the internal dynamics of citizen projects, specifically as they relate to questions around power, consensus and conflict. Another limitation has to do with the demographics of my interviewees. While I interviewed men and women of various ages, other factors such as race and class did not vary much. My interviewees, therefore, were predominantly white and middle-class. I believe that this research could have benefited from interviews with people of different socio-economic and racial backgrounds, especially given their absence from many of these citizen UA projects.

Before delving into empirical findings followed by an analytical discussion, the following section provides some historical context on UA in Montreal. Here, I will trace how UA has evolved over the last century, looking at its particular functions, both within 
Montreal's formal municipal structure, as well as within grassroots organizations and citizen initiatives. 


\section{Section IV.}

\section{UA in Montreal: Historical roots and current trajectory}

According to a survey administered by the City of Montreal in 2013, 42\% of residents practice UA (Ville de Montreal, 2013). This number takes into account all scales of food production: from growing herbs in indoor pots, to commercial rooftop farms, community gardens, or school gardens. This amounts to over 800,000 people cultivating fruits and vegetables within the city limits. These trends in urban food production are not limited to Montreal, as cities throughout North America and the West in general are experiencing a widespread enthusiasm for UA. As we will see with the case of Montreal, these trends stem from a long history and culture of urban gardens. To better understand the contemporary landscape of UA in Montreal, this chapter provides an overview of how social, economic, and cultural circumstances have shaped urban food production.

\section{Historical Roots of Urban Agriculture in Montreal}

Urban gardens have been a feature of cities for centuries. Yet, the scope and nature of food production has evolved in important ways. Up until the early $20^{\text {th }}$ century, urban food gardens were primarily found in backyards or courtyard spaces, directly

connected to private habitations. It wasn't until early on in the $20^{\text {th }}$ century that food production shifted from being a private to a public activity. Prompted by economic instability and war, new spaces outside the home were converted for large-scale food production. In Montreal, these types of gardens became widespread as early as 1909 . Many of them were established by reformist organizations such as the City Improvement 
League of Montreal, whose members believed that gardening initiatives would contribute to alleviating hunger amongst the poor and working class (Saint-Hilaire-Gravel 2013). Later known as Victory Gardens, these spaces of urban food production became ubiquitous throughout North America during the First World War, contributing to food security at times of precariousness in food provisioning. In Montreal, the Community Gardens League (CGL) launched a broad community gardening program in 1932 for working-class and unemployed families. The outcomes of this program were manifold, and included social, economic, and political benefits. With the onset of WWII, another wave of Victory Gardens appeared. In 1942 the CGL along with the Ligue Ouvrière Catholique (LOC) launched the Victory Gardens program as a war effort, which resulted in over 150,000 Montrealers having access to a gardening plot by 1944 (Saint-HilaireGravel 2013). After the war ended, the number of Victory Gardens declined, and during the 1950s many community gardening programs dissolved. Yet food production was on the rise, this time again in the private sphere, as many Italian and Portuguese immigrants converted their courtyards into highly productive vegetable gardens. The area of the city where they settled, since termed 'Little Italy', is to this day a haven for urban agriculture; beyond private yards, the back alleys are lined with grapevines and other fruit trees and shrubs.

\section{Institutionalizing UA: Montreal's Community Garden Program}

Individual and community efforts continued to develop, this time prompting official government interest. After a lull in the post war era, new gardening initiatives began to take form in the mid-1960s and early 1970s. This coincided with the election of 
mayor Jean Drapeau of the Action Civique party in the 1960s, a time when Montreal went through a phase of modernization and urban redevelopment. These changes are best understood as a byproduct of broader post-industrial restructuring. Within this context, a new wave of community gardens (jardins communautaires) emerged in the early 1970's, which subsequently coalesced into an organized network of gardens. Community gardens are defined as a "parcel of land divided into garden plots [where] each plot is cultivated autonomously by an individual or a family" (AU/LAB 2016). This renewed interest in UA grew out of the energy crisis of the 1970's and the nascent environmental movement (Massé et Beaudry 2008; Wegmueller et Duchemin 2010).

Community gardens are a defining feature of UA in Montreal. According to Eric Duchemin $(2013,39)$, "Montreal is the city that has developed this form of urban agriculture the most" in North America. Interestingly, the first community garden was established by a group of citizens in 1974, leading soon after to the creation of dozens of other gardens. It wasn't until the following year that the city became involved in the maintenance of these spaces, and launched its municipal Community Gardens Program, supported by the Botanical Garden. In 1977, the Botanical Garden formed the Joint Committee of Community Gardens (Comité Conjoint des Jardins Communautaires), a committee that worked alongside citizens, but nevertheless created a set of rules for community gardens, such as banning the cultivation of corn and potato.

By 1980, community gardens were largely integrated into the municipality, and were viewed as an extension of the Botanical Garden. In 1986 the management of the Community Gardens Program was transferred to the Recreation and Community Development Services (Services des Loisirs et du Développement Communautaire). In 
2002, management of the Community Gardens Program was passed down to the individual boroughs, something that had an overall positive impact for the program. In fact, these changes allowed boroughs to cater the program more specifically to the needs of their populations. The Community Gardens Program remains very successful to this day: with over 100 gardens, it is estimated that between 12,000 and 15,000 Montrealers have a garden plot. Community gardens have become so popular that today the majority of them have waitlists. According to a newspaper article published last year, the Rosemont-La-Petite-Patrie borough has over 1,000 names on their community garden waitlist, while the Plateau-Mont Royal has just under 1,000 (Provost, 2015).

\section{From Community to Collective Gardens}

While still ubiquitous in the current UA landscape, community gardens are by no means the only spaces for UA. Indeed, since the mid 1990s, other types of UA have emerged in Montreal, specifically in the form of collective gardens (jardins collectifs). In many ways, the growing interest in establishing collective gardens came from the limitations of the existing Community Gardens Program. As mentioned above, the institutional nature of the program led to the implementation of numerous regulations, whose purposes were to ensure safety and provide standards for food production. As Janvier and Doucet $(2015,2)$ explain, "these regulations accumulated over time, limiting what could be grown, what techniques could be used and who was allowed in the space." Additionally, long waitlists to obtain a plot have remained a significant barrier for those wanting to produce their own food. Overall, there was a sense that the institutionalization 
of the program had somehow lessened the ability of gardens to become spaces of community mobilization (Action Communiterre, 2004).

In practical terms, a collective garden consists of one parcel of land that is cultivated in common by a group of individuals. Whereas the spatial arrangement of community gardens into individual plots tends to limit interaction amongst gardeners, one of the main goals of collective gardens is to bring a diversity of people together, encouraging them to work cooperatively, make decisions collectively, and share the harvest. Largely coordinated by grassroots community organizations, collective gardens have taken a more explicit political stance, reorienting these spaces towards uses beyond food production (Massé and Beaudry, 2008). While community gardens were primarily used for recreational and educational purposes, collective gardens shifted the focus to issues of poverty, social rehabilitation (reinsertion sociale), food security, and citizen empowerment. Some have also argued that their emergence can be linked to broader political-economic processes, and can thus be understood as a reaction to a growing sense of social exclusion and increasing unemployment (Massé et Beaudry 2008).

The first collective garden, Le Jardin Cantaloup was created by the organization Action Communiterre in 1997. Since then, dozens of collective gardens have emerged throughout the city. In 2006, collective gardens were brought together under the nonprofit group Regroupement des Jardins Collectifs du Québec (RJCQ), whose aim was to simultaneously help develop new collective gardens and support existing projects. Despite the creation of the RJCQ, collective gardens remained quite isolated from one another, insofar as they were part of distinct community organizations. Indeed, even though they stayed in the RJCQ network, the 42 collective gardens at the time were run 
by at least nine different organizations, each of which determined the structure and functioning of their gardens (Duchemin 2013).

\section{The City's Eco-quartier Program}

Although not solely focused on UA, it is worth mentioning Montreal's municipal environmental program, the Éco-quartier program, founded in 1995. The Éco-quartier program is run at the level of the individual boroughs, where funding is given to independent non-profit organizations contracted by the boroughs. These organizations must submit a proposal in order to be chosen, and to a certain extent, they must meet some of the borough's specific demands (Sénécal 2002). When it was first implemented, the program emphasized three specific realms related to the environment: cleanliness, recycling, and beautification (Sénécal 2002). To this day, one of the program's goals is to encourage citizen participation, notably "to increase public awareness of environmental issues and to encourage citizens to take responsibility in this area" (Sénécal 2002, 51). It was only in 1998 that the program started to move in the direction of environmental activities. Since then, much more has happened $\mathrm{n}$ the realm of environmental issues.

It is important to mention that the different boroughs' Éco-quartiers programs are quite different from one another. This is because the programs usually respond to very localized issues. In some neighborhoods, the emphasis is placed on recycling, for instance, while in other neighborhoods there is more of a focus on horticultural and UA activities. Additionally, the breadth of activities ultimately depends on funding. According to Sénécal (2002), there is often competition for funding, as organizations compete for grants. Furthermore, some of the Éco-quartiers are able to employ up to 20 
workers, while others have a much smaller budget and are only able to hire a coordinator as the sole paid employee. In this sense, UA is not on the agenda in each and every borough, and funding plays an important role regarding what these programs can or cannot accomplish.

\section{Citizen-led UA Projects}

Over the last six years, individuals and groups of residents have increasingly been the ones initiating urban gardens. These initiatives, generally referred to as projects citoyens ("citizen projects"), have emerged in underused or interstitial - yet often highly visible - spaces: on sidewalks, median strips, or vacant lots, to name a few. In some ways, these projects bear resemblance to the practice of guerilla gardening, which is "the illicit cultivation of someone else's land" (Reynolds 2008, 16). Some participants abide to the more contestatory ethos of guerilla gardening, and view their actions as a way of challenging capitalist urban development. For others, it is merely a fun activity that contributes to the beautification of their neighborhood. As we will see, despite the use of guerilla gardening tactics in many citizen-projects, the emphasis seems to be less on illegality and more on improving urban spaces. Moreover, while usually initiated informally, citizen-projects tend to receive the eventual support of the municipality. These relationships vary from one project to another, as support can come from different places: oftentimes, community organizations provide material assistance to projects, while larger non-profits supply grants. In some cases, there is municipal support and even advocacy for citizen initiatives. As Cohen and Reynolds $(2014,4)$ astutely claim, "formal policy processes can respond to informal networks, and networks of advocates can be 
oppositional while simultaneously participating in formal policy processes." In this sense, citizen projects present us with complex assemblages not easily characterizable as either guerilla or institutionalized. Rather there is a hybridity to these initiatives; the relationships that develop with non-profits and the municipality are not negligible; in fact they are in many ways what guides projects and allows them to grow, something I will address more thoroughly in the following section.

\section{Towards a Comprehensive UA plan: Montreal's Public Consultation on UA}

The many types of UA in Montreal are one of the reasons why it has been so difficult for the City to create a comprehensive plan on UA. This complexity can partially be attributed to the transfer of the Community Gardens program from the City to the boroughs in 2002. Montreal's nineteen boroughs each have their own governmental structure independent of the central City municipality. Boroughs have their own elected mayor and municipal officials, and function independently when it comes to territorial governance; for instance, each borough is in charge of its own urban planning, waste management, parks, as well as social and community development. This intricate governance structure has rendered difficult the creation of a comprehensive UA plan, able to take into account the different boroughs' social, economic and environmental concerns. Thus, boroughs like Plateau-Mont Royal and Rosemont La-Petite-Patrie devote many resources towards UA, seeing it as a major concern within their particular boroughs. Yet in other, less central boroughs, UA is not much of a priority.

Furthermore, other difficulties in grappling with the administration of UA in Montreal are linked to UA's inherent multifunctionality. The multifaceted nature of UA 
has often left planners and municipal officials unsure about which branch of government is best suited to take on UA. Only in the last decade or so, has the City of Montreal formally integrated UA in its development plans. In its 2005 Master Plan, the city only mentioned community gardens in passing, failing to recognize the multidimensionality of UA. However, in its five-year (2010-2015) Sustainable Development Plan, the city addresses UA more thoroughly, particularly recognizing its role in reducing the urban heat island effect and contributing to urban biodiversity.

In response to the lack of municipal leadership, citizens and non-profit organizations came together in 2010 to form the Groupe de Travail en Agriculture Urbaine (GTAU), the Urban Agriculture Working Group. This coalition brought together over forty UA organizations and practitioners, including the RJQC and the CRAPAUD ${ }^{4}$, both of which have been central actors in the field of UA. The CRAPAUD is a research collective at the University of Quebec in Montreal (UQAM) that has been at the forefront of UA research, both from a scientific and social perspective. In 2012, the GTAU initiated a petition calling for a consultation publique (public consultation) on UA. The petition reached an overwhelming 30,000 signatures, twice the number required to hold a public consultation. This participatory process of public comment conducted by Montreal's Office of Public Consultation (OCPM) consisted of a series of meetings throughout the city in late spring of 2012. This process brought together citizens, city officials, and non-profit organizations in an open dialogue on the state of UA in Montreal and its future directions. With a total of six information and exchange sessions in May

\footnotetext{
4 The CRAPAUD stands for "Collectif de Recherche en Aménagement Paysager et en Agriculture Urbaine Durable." The acronym CRAPAUD also means 'toad.'
} 
and June 2012, the consultation process brought together 260 people, of which 59 voiced questions and concerns. One of the main concerns brought up by citizens and non-profits was the need for city officials to more openly recognize and endorse UA projects. Ultimately, three main demands came out of the public consultation: 1) to explicitly mention UA in official documents and city plans; 2) to review the regulatory frameworks governing UA practices; and 3) to increase the availability of stable and recurrent financial support for UA.

Although the public consultation mobilized Montrealers and their representatives, significant advances in UA policy have yet to be seen. In spite of the city's public support of UA, many of the same issues facing UA practitioners before the consultation persist today. The report published by the City after the public consultation represents a step in the right direction, particularly in its recognition of the multidimensionality of UA; indeed, whereas previous official documents mainly emphasized the environmental benefits of UA, this new report also sheds light on UA's social and economic dimensions. Ultimately, while UA is starting to be understood as a key element of sustainable urban planning, many practitioners and advocates of UA agree that much remains to be done in terms of implementing better programs and policies (Etat de l'Agriculture Urbaine à Montreal: Rapport de la Consultation Publique, 2012). 


\section{Section V. Findings:}

\section{Understanding the dynamics of citizen-projects}

\section{Why are vacant and underused spaces being reappropriated for UA? \\ Limitations of Existing UA Infrastructure}

In many ways, the emergence of informal citizen-led UA projects in Montreal reflects the limitations of existing UA programs and infrastructure. As mentioned earlier, the institutionalization of the Community Gardens program in the 1970's led to the implementation of numerous regulations, with the purpose of ensuring safety and providing standards for food production. Community gardens can therefore be seen as somewhat insular spaces, insofar as they are fenced off and accessible only to members.

Although the collective gardens that emerged in the 1990s fostered new gardening practices and encouraged stronger social relationships, they have their own limitations. One participant - who is now part of a citizen-project - encountered these kinds of issues in the collective garden he previously belonged to: "I was part of a collective garden, and at one point, I told the garden manager, 'I want to put flowers here', and he replied: 'We

don't cultivate flowers here, we cultivate vegetables." Additionally, although collective gardens are more accessible in comparison to community gardens, there still remain barriers to access. In fact, these gardens are often established on land owned by churches or other community organizations, and are therefore not as visible or accessible. As Janvier and Doucet $(2015,3)$ explain, "low visibility and misconceptions [are] yet another obstacle to transformation of urban sites into gardens." 
Informal citizen-projects have sprung up throughout the city in the last several years. A defining characteristic of these projects is their location; indeed, these kinds of gardens are taking root in underused or interstitial spaces, such as sidewalks, vacant lots, spaces around trees, or on median strips. These spaces are therefore highly visible and accessible. According to a community member active in several of these gardens,

These projects are emerging everywhere. For about three years, there's been a buzz in Montreal (...) but more and more citizens are leading it. Citizens have the desire to get involved, beyond the university setting and beyond more established groups that have initiated the movement. Now, more citizens want to take charge of themselves.

These changes point to a rethinking of what the individual - as well as groups of residents - are capable of doing when it comes to transforming their living environments. Doing this outside of the institutional realm allows for new and unexpected interactions. A resident of the Rosemont borough who started a garden on the median strip in front of her apartment reflects on the distinction between citizen projects and more formal collective gardens. She claims: "I found that even collective gardens remained closed and restricted to the population. A lot of people don't know they exist, or they might feel uncomfortable making an official request to join a garden." Therefore, it seems that the open nature of participation in these projects can give people more flexibility in terms of their commitment and involvement.

Overall, the limitations of formally established community and collective gardens have played an important role in the inception of citizen UA projects. Yet different motivations and goals are driving individuals and collectives to start new projects. For the sake of clarity, I draw a distinction between environmental, social, educational and political motivations, while keeping in mind that these are necessarily interrelated. As 
mentioned earlier with the concept of multifunctionality, the various outcomes of UA suggest that people are motivated by more than just food production. Nevertheless, producing food remains a core motivation for certain groups, particularly those working with food insecure populations. The following sections uncover some of the central motivations behind the rise of UA citizen projects.

\section{Environmental dimension}

Environmental issues are a major incentive for the establishment of UA citizen projects and the reappropriation of space in Montreal. ${ }^{5}$ For many participants, planting a garden is a direct way of creating a greener, more sustainable city. Urban agriculture has myriad environmental benefits; as Wegmuller and Duchemin (2010) explain, UA can help diminish the urban heat island effect, improve air quality, and increase biodiversity. In this sense, these projects can be situated within broader efforts to combat climate change and the transition towards more sustainable cities. For the mayor of the Rosemont-La Petite-Patrie borough, the environmental dimension of these projects is highly important. He claims: "of course the first advantage [of UA] is environmental, it allows to increase the greening of public space and to reduce the mineralization of soils, which has a direct impact on heat islands." Similarly, other municipal officials view UA as a critical tool for greening the city. According to a city councilor in the Verdun

\footnotetext{
${ }^{5}$ It is important to explain the use of the term reappropriation in this particular context of land reappropriation. Indeed, this term is problematic in that it can efface the history of the land as belonging to Indigenous peoples. Because participants directly use this term when describing their involvement in these projects, I decided to use it throughout this paper. Thinking of reappropriation from a Lefebvrian perspective, we can come to better understand this concept as the reappropriation of the production of urban space rather than a claim to ownership. From this perspective, users of space "reverse the process by which urban space is being made strange to them and reclaim the control of space for themselves" (Purcell and Tyman 2015, 1135).
} 
borough, many ecological benefits could come from integrating more fruit trees and shrubs in parks and on city streets.

Additionally, these projects draw attention to the unsustainability of the existing food system, and thus implicitly or explicitly articulate a critique of the corporate agrifood system. This is a message that one of the more subversive projects, the Jardin du Marché ("the Market Garden") is putting forth. A central goal, according to a co-founder of the Jardin du Marché, is to encourage a heightened environmental consciousness. Indeed, the location of the garden, adjacent to one of the city's largest and most frequented farmers' markets, is in itself a criticism of the global food system. This is because many of the products sold at the market actually come from far beyond the province of Quebec, and many more are products of conventional large-scale agriculture. As one of the founding members notes: "We believe that a contact with the soil will motivate [people] to learn more, to learn where their food comes from, and to maybe modify their eating and buying habits." Thus, a central mission of the Jardin du Marché is to create a space that prompts people to think about larger questions pertaining to the relationship between humans and their environment. For many people involved in UA projects, reintroducing agriculture and food production in the city is integral to creating a healthier and more sustainable food system. The same member insists on the importance of the space's longer-term "agricultural vocation", suggesting that organic food production represents the best possible use of this space. Although there is a risk that the municipality will remove the garden, the group doesn't see this as a problem so long as the space remains dedicated to food production: "What we want in the long term, is for the agricultural vocation [of the space] to perpetuate." 
Related to this critique of the global food system, there has been a push within UA projects, to understand the city - and its inhabitants - as part of a larger ecosystem. Many of the initiatives that are emerging are drawing from more holistic and integrated understandings of nature and society. Specifically, these groups are applying permaculture techniques. Permaculture is "an approach to designing human settlements and perennial agricultural systems that mimics the relationships found in natural ecologies" (Holmgren 2010). For one of the members of the Jardin Pour Tous ("Garden For Everyone"), the principles of permaculture represent a concrete way of changing cities, particularly of transforming inert spaces into living and healthy urban ecosystems. Moreover, a systems approach can have positive repercussions beyond food production, insofar as it has the ability to fundamentally transform how we relate to our environment and to ourselves. An active member of the Jardin Pour Tous explains: "Now I cultivate in a living soil, to produce seeds, not just to eat. It means preserving biodiversity within our food systems, and to increase it if possible, and to promote cultivation of ancient varieties."

For others still, these initiatives are opportunities to beautify and revitalize neglected spaces. From this perspective, the purpose of these projects is to make neighborhoods more "livable" and aesthetically pleasing. For one of the founders of the citizen group $\mathrm{CHAPEAU}^{6}$, based in the Hochelaga-Maisonneuve borough, "the revitalization of spaces [is clearly important], to plant on abandoned tree spaces, as well as by the entrance of the Metro. It makes it more beautiful, and it also makes people

\footnotetext{
${ }^{6}$ The CHAPEAU stands for: Comité d'Hochelaga Autour du Partage et de l'Education en Agriculture Urbaine. The acronym 'CHAPEAU' means 'hat.'
} 
proud of their neighborhood." The desire to turn vacant or underused spaces into beautiful, green spaces, is something that many participants have expressed, although it is often just one of many objectives for a project.

\section{Educational Dimension}

A main endeavor of informal UA projects is to promote education, particularly through hands-on learning. Oftentimes, participants with more horticultural skills will share what they know with those who are new to gardening; yet learning is often understood as a mutual process, encompassing skills and lessons beyond horticulture. Thus, people are encouraged to join a group even if they don't have gardening skills, and to simply learn in the process. In some ways, people are encouraged to 'auto-educate' themselves, to learn by trial and error. At the Jardin Pour Tous, children put together a little pathway, writing the names of plants on rocks. One of the founders explains the importance of learning as both "intuitive and educational," insofar as the acquisition of knowledge in this context is sensory-based. While these projects are highly intergenerational, a lot of emphasis is placed on educating children. The educational component is central to the work done at the non-profit La Maisonette des Parents ("the Parents' House"). According to the garden manager: "Teaching our kids that a grain can grow, how it grows, but also how to use it as an organic fertilizer. And so that kids can learn how to fertilize their garden, otherwise it's magic, but there shouldn't be any magic, they have to see the work that is behind it."

Beyond horticulture, education also takes place between people, as participants are exposed to new practices, such as cooperation, collective decision-making, and 
sharing (of food and responsibilities). The non-profit organization Alternatives partners with citizen-projects to teach them these particular skills, "promot[ing] knowledge sharing through conferences, workshops and community meetings" (Janvier and Doucet 2015, 4). Navigating these interpersonal relationships can be challenging, yet an interesting exchange of knowledge takes place, as people learn from different perspectives and navigate uneven power dynamics.

Similarly for the La Maisonette des Parents, which works primarily with food insecure populations, achieving individual autonomy is a central part of their mission. The manager of their 17 collective gardens believes it is crucial to "teach that to children, this notion of sharing. I am preparing a generation of children who will be better adapted to this aspect of 'vie citoyenne' (civic life) that are collective gardens, Incredible Edibles, this type of thing. So children who will understand the importance of cultivating space." He goes on to explain the shifting attitude of the children towards sharing the food grown in these spaces. In the beginning, if the kids noticed that a tomato had been picked, they would react by saying, "Oh no, somebody stole our tomato!" but when the same thing would happen later on, they reacted positively and would say, "Yay, somebody took a tomato!" These perspectives and attitudes, perhaps more than the gardens themselves, are essential to building a sense of collective ownership, identity, and community. The Jardin Pour Tous espouses similar values around sharing. One of the core members explains: "I think that what's interesting when we start cultivating a garden, [is that] it's not simply producing food, but it also opens doors to having conversations with others, and it inspires others to give as well. Because there is abundance when you work with nature. 
So often at the end of the season, we always find ourselves with too many tomatoes" (CIBL, October 27, 2015)

Ultimately, the site of the project is usually presented as an educational tool in and of itself, as a site of demonstration for what can be accomplished elsewhere. One recurring motivation across these different projects is to show that growing food can be easy and accessible to all. Thus, many participants advocate for UA as something that anybody can take part in, and many participants view the garden as a site of education and demonstration. In some way, there is a sense that all of these projects are being influenced by one another, and fostering an informal network of social and ecological relationships.

\section{Social Dimension}

Bringing people together and building community is an important aspect of citizen UA projects. For Gaëlle Janvier, Executive Director of Alternatives, the social is possibly the most central dimension of these initiatives: "I think that often people like to do UA projects because they want to produce, they want to cultivate...but all things considered, they don't say it, but what they want is to meet people and to be outside." Initiatives like the CHAPEAU and the Mange-Trottoir ("Eat-Sidewalk") clearly reflect these dynamics. Because this garden is situated on a busy intersection, it makes it easier for residents to cross paths and to start conversations with one another. These projects then, create opportunities for people to foster a sense of community. The founder of the sidewalk garden Beaux d'Écores ("Beautiful Decorations") in the Rosemont borough reflects on how this sense of community developed after she started her garden: "we 
noticed that Beaux d'Écores was becoming a place of sharing, a pretext for neighbors to talk and meet each other. It creates extraordinary moments.” These projects further tend to bring together people with different backgrounds and interests. Throughout my fieldwork the intergenerational dimension of these projects stood out. The project CHAPEAU has brought together people of different ages and professional backgrounds, who might not have interacted if it weren't for the UA project. A member of the group explains, "I find it great, there are people of all ages (...) most people do not work on greening the city, they don't deal with this in their daily work, we have graphic designers, computer engineers, an accountant, it's really people from all horizons."

Within citizen groups, strong bonds are often formed, which extend beyond the short growing season. In the winter, efforts are made to keep the momentum going through organizational meetings and Facebook discussions about the upcoming growing season. In the spring and fall, other events and workshops are organized; for instance, Un Jardin Pour Tous planned a Halloween brunch in the fall and a seeding party in March. In the summertime, participants will often share meals together made with vegetables from the garden after work parties. These events are essential to fostering a strong sense of community. Other groups like the Mange-Trottoir function similarly, and have regular meetings to discuss the garden around food and drink.

Yet, within other groups, having a tight-knit community is less important. For the Jardin du Marché, the objective is not so much to have a well-organized group of people, but to have a more autonomous structure, where people can decide to help out - or not whenever they want. About this, a founding member states: "It is a completely open management [of the garden]. We don't know who comes. Plenty of people have 
expressed interest in participating in this project. If they come or not, we don't know." While the idea of completely open management may sound appealing, this has caused some issues in the garden. In fact, the three founding members of the garden end up with additional chores and responsibilities (such as watering), because people tend to help out for a little while and then move on to a different project. In this particular case, the lack of regular communication - such as creating a weekly watering schedule - can be detrimental to the project, and cause people to become less involved.

\section{Political Dimension}

The momentum for transformation is evident, especially in the more central boroughs of Rosemont-La Petite-Patrie, Villeray, and Hochelaga-Maisonneuve. Beyond the specific goals of each initiative, there is a general focus amongst participants on seeing UA as a movement. One of the founding members of the Jardin Pour Tous reflects

on how these new community-led projects are a departure from the existing UA landscape in Montreal. Indeed, these projects are creating new opportunities for people to experiment with "democracy and open participation." For him, part of the enthusiasm around citizen UA was prompted by the "Maple Spring" student uprisings of 2012. That year, university students across the province went on a six-month strike to protest tuition hikes and the privatization of education in the province of Quebec (Spiegel 2014). Much of the strength of this movement came from its deliberate use of spatial practices as a means of resistance and contestation. While there remain tensions between short-term political action and long-term systemic change, the 2012 student strikes made clear that 
movement building is a necessary step towards the creation of alternative socio-political arrangements.

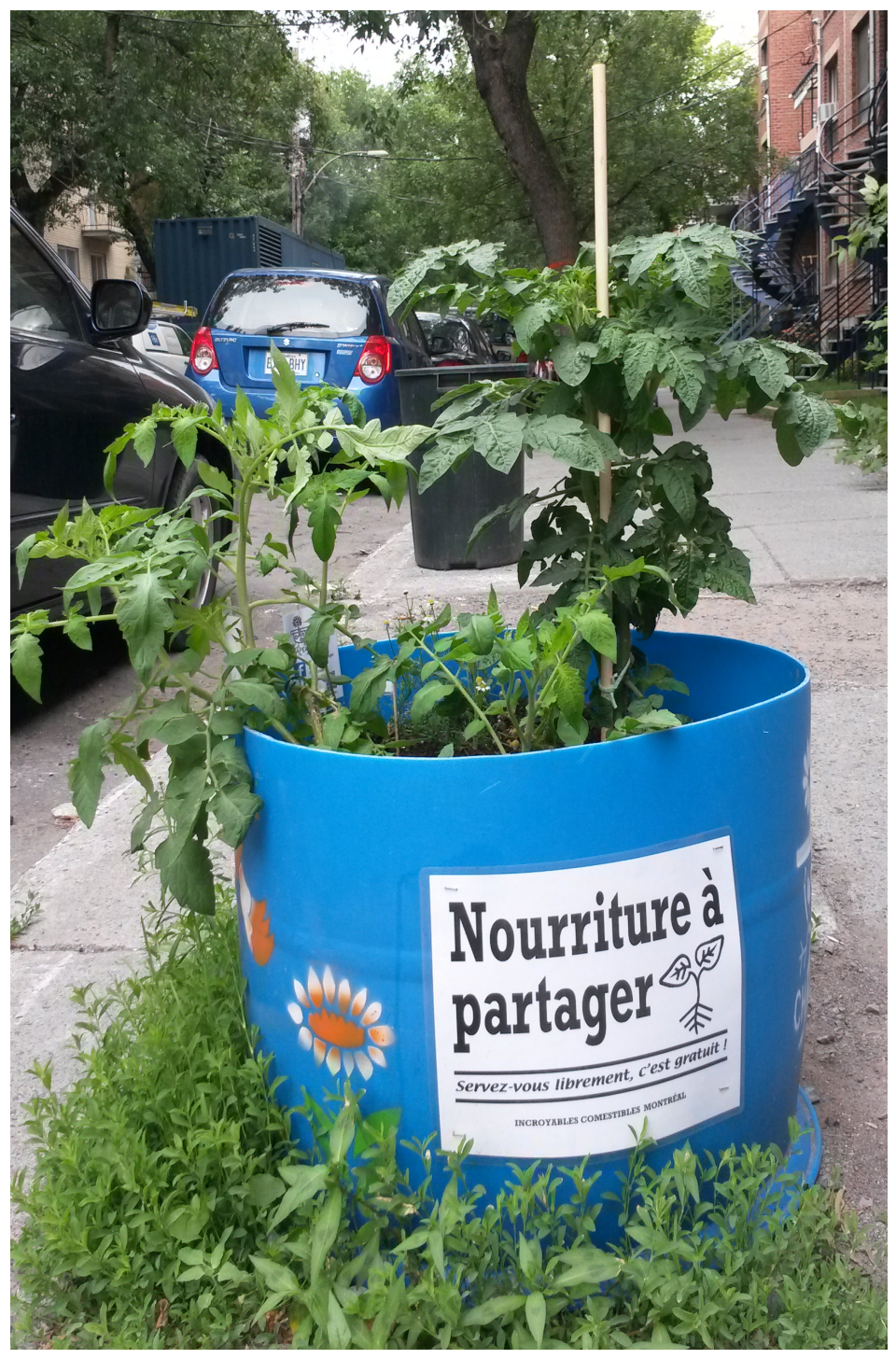

Figure 4. The CHAPEAU's 'Plant Everywhere' initiative 
The spread of community-led UA reflects a desire to keep planting more, in more places, and to involve more people. For members of CHAPEAU, being a "part of the action" is a main motivation. While the group has gone through several bureaucratic hurdles, one of the interesting features of the CHAPEAU is the possibility for people to act, to exert agency in their everyday environments. For one of the core members of the CHAPEAU, it is important to retain this focus on practical change in spite of less appealing tasks, such as dealing with bureaucracy. About this, she explains, "What we wanted most perhaps, was to be in the action, to add more [containers/gardens]." One of the group's two projects is called Planter Partout, which litterally means "Plant Everywhere". It comprises 80 large blue planter pots scattered throughout the HochelagaMaisonneuve borough. The project is quite unique in that it is highly visible, mobile, and dispersed. These containers (Figure 4) can be found on the sidewalks of major commercial arteries such as the rue Ontario, as well as along residential streets and back alleys. Residents and business owners volunteer to take care of one or two containers. The same member explains how this structure allows people more flexibility, and the ability to practice UA at at a scale they can more easily manage. In a way, this project brings UA directly to peoples' doorsteps. It exists at the boundary between the private sphere - the container as an extention of the private garden - and the public sphere, given its location on sidewalks.

The non-profit Alternatives takes a similar approach to starting UA projects. Since 2003, the organization has put forth a model for an out-of-ground container, made out of recycled materials, making it easier to replicate and move from one location to 
another. Furthermore, the mobile character of these containers has a direct impact on the longevity of a given project. According to Janvier and Doucet $(2015,3)$ :

These out-of-ground containers also provided a solution to problems of insecure land tenure: collective gardens sometimes rely on informal agreements, whereby landowners will allow citizens or local organizations to use their space for an undefinted amount of time. These partnerships can end, or alternatively, spaces can become unsuitable for plants or people. The containers we developed enable the relocation of gardens.

Ultimately, the mobility of these UA projects demonstrates their degree of adaptation to some common obstacles that usually impede these initiatives. Assisting citizen groups throughout the creation of UA projects is central to the organization's vision of "using gardens as a space for fundamental social change" (Janvier and Doucet 2015, 5).

\section{Making Food Free to All}

All of the citizen-UA projects studied here, relate in some way or another to the decommodification of food. Indeed, the food cultivated in these spaces is intended for everyone, not just those who planted the seeds and tended to the plants. To some extent, these practices have been influenced by the Incredible Edibles movement, which emerged in a small town in the United Kingdom in 2007. One of the main motivations of this movement is to give anyone the ability to harvest fruits and vegetables, regardless of whether they are part of a project or not. This practice quickly spread to other towns and cities throughout the world. Many of the citizen projects in Montreal exist under the banner of the Incredible Edibles network (usually recognizable through signage), and ascribe to the philosophy that food should be free. For the CHAPEAU, the production of vegetables for all to consume, is a main motivation to continue planting everywhere. 
While the residents in charge of a blue container are often referred to as 'owners', they do not actually own the vegetables grown (or the containers). A member of the CHAPEAU explains: "We are very clear from the start with people around this: you are responsible [for the containers] but these aren't your own plants, you offer them to everybody." Yet, making garden produce available for anyone to harvest has its own set of challenges. Many participants have expressed that oftentimes, vegetables are harvested before they are ripe, and in ways that damage the plant. In an effort to address these challenges, many groups have made little signs that they put next to vegetables, informing people if it is ripe, and how to go about harvesting it. Furthermore, while more and more edible spaces are being created, there is also the recognition that edible spaces already exist within the city. Indeed, many alleys - especially in the Petite Italie neighborhood - are full of fruits and berries. As the garden manager from La Maisonette des Parents explains: "Here there are free grapevines all along the fences on both sides (...) there is free food all around us (...) the neighborhood overflows with edible spaces like these ones."

Making food available for free is also a tangible strategy for addressing food insecurity. Yet, community members don't view these issues as the primary function of citizen UA projects. In this sense, food security is more so carried by non-profit organizations like La Maisonette des Parents and Carrefour Alimentaire Centre-Sud. As the director of the Carrefour Alimentaire Centre-Sud explains, it is important not to romanticize the role of UA in solving food insecurity. He says: "We have a huge collective garden, and everyone leaves with three cabbages, three broccolis and three cauliflowers, it's good but will that guarantee food security? It contributes to it surely 
(...) but there's often this preconceived idea of 'let's build gardens it will feed the world."

\section{How Are Citizen-Projects Being Established?}

Although each citizen project is unique, there are nonetheless a number of overlapping approaches and strategies that play into the development of these spaces. In this section, I examine the various processes by which citizens are reappropriating spaces for UA: How exactly is space being negotiated with other actors and stakeholders? Are there specific strategies and tactics that groups are using to facilitate these processes? What kind of support - financial or otherwise - are they receiving from outside institutions or organizations? What are the major barriers for the establishment of citizen projects? As I will demonstrate, there is no clear protocol for accessing and transforming these spaces; rather, it is often a messy and complicated practice that varies from one project to the next. Indeed, this process depends on myriad factors, such as internal group dynamics, relationships with municipal officials, or even just good timing. Yet it is possible to discern some common approaches. I begin by discussing bottom-up approaches to reappropriation, in which groups of citizens take initiative for the creation of UA spaces without formal approval from the municipality. Then, I address the complicated task of navigating partnerships with city officials as well grassroots organizations working on UA, and how this affects what happens on the ground. Finally, I discuss the question of institutionalization of citizen projects at the borough or city level, and what the implications of institutionalization might be for projects. Specifically 
I will interrogate the relationship between the institutionalization of citizen projects and the potential for de-politicization.

\section{Community Members Taking Initiative}

Many citizen projects began without the assistance or even the approval from the municipality. This approach is most closely associated with guerilla gardening, which is the illicit cultivation of land. In practical terms, residents take the initiative to organize an initial meeting through online forums such as Facebook groups. The formation of a core group of participants is often the first step in the process of creating an informal garden. The Mange-Trottoir is a sidewalk garden initiative in the Villeray borough that began to take shape in the winter of 2014, when neighbors got together and came up with the idea for the project. The group created Facebook page with the purpose of facilitating conversations and exchanges between community members. This platform has proven to be crucial in terms of organizational and logistical planning. To this day, the Facebook group is the primary platform for communication, something that is also true for other groups like the Jardin Pour Tous and the CHAPEAU, for instance. The Mange-Trottoir comprises several raised garden beds at the busy intersection of rue Drolet and rue De Castelnau, located in the median between the sidewalk and the street. The project has expanded and also includes a Little Free Library, a sitting area, and more recently an "insect hotel". According to one of the core members, the novelty and success of the project has drawn people from other cities in Canada, as well as from Belgium and France. Additionally, many news outlets have come to interview members of the MangeTrottoir. When discussing the reasons behind the project's success, this same participant 
insists on the importance of citizens taking initiative from the start, as opposed to approaching the City with a request. He explains: "I think it is necessary to push those in charge a little bit, to provoke them. If we had presented the project at the start in its final version, with the raised beds and all that, there are chances it would've been completely dismissed." Furthermore, the two core members who went to present the project at the City Council meeting were not originally authorized to do so. They were only allowed to attend the meeting and sign up to ask questions, but they bypassed the existing protocol and decided instead to present the project to the City officials. This kind of strategy proved to have a positive effect, insofar as it showed the City that the group had thoroughly thought this project through, and that they were serious about going ahead with it. Although the City and borough do not support the project financially, they have allowed citizens to continue cultivating these spaces. As one of the founding members explains, "Now that we are more accepted by the municipality, we want to add an insect hotel, a cold frame, as well as workshops on insects, plants. We are even thinking of eventually adding an artistic dimension." We see here that the process of reappropriation is unforeseeable and dynamic. In the case of the Mange-Trottoir, a lot has depended on a strong organizational core and on strategic negotiations with city officials. Rather than asking permission, the group went ahead and started the project, and little by little, earned the trust and approval of elected officials. Furthermore, the outside perception (from the media, visitors and so forth) has played an important role in legitimizing the project.

But starting gardens outside of existing structures and organizations can also be challenging, especially when citizens with little horticultural knowledge decide to undertake these projects. From the perspective of staff members at Alternatives and $\mathrm{La}$ 
Maisonette des Parents, not all community-led initiatives will flourish into something. Indeed, some residents plant crops in interstitial spaces, such as the spaces surrounding trees, without taking into account issues of pollution or soil contamination. In this sense, there sometimes needs to be more consideration and planning before instigating a project. As the garden manager at La Maisonette des Parents puts it, "it's not because there's a [vacant] lot that we will do something." Additionally, without a tight-knit group of citizens, projects tend to dissolve relatively quickly. The same manager explains that several of the raised beds built by citizens under the Incredible Edibles banner often become neglected. In other cases, they are utilized but people lack knowledge and harvest vegetables too early or in ways that damage the plants. Perhaps one of the greatest challenges does not lie within the initial establishment of a garden, but rather in its continuity. My interviews and participant observation suggest that this is contingent on myriad factors, but most fundamentally, it depends on internal group dynamics and people's interest in the project. Yet, community members are not always on their own when it comes to creating and supporting UA projects.

\section{The Involvement of the City}

Overall, support from the City remains marginal. The boroughs, on the other hand, will oftentimes help remove barriers to the establishment of citizen-projects. Yet, there is often little overlap between the City and the individual boroughs. Indeed, there is a sense among UA practitioners that the City of Montreal is not particularly concerned with further developing UA projects. Furthermore, there seems to be a disconnect between the overall goals of citizens and those of the municipality. A staff member from 
the non-profit organization Santropol Roulant reflects on the creation of the Permanent Committee on UA after the public consultation in 2012. Although the committee was a positive step forward, it remained that bureaucrats had a very different vision than community organizations and citizens on matters of UA. These differences have made it difficult for effective collaborations to take place.

Additionally, although some city officials are starting to pay attention to citizen reappropriation, there are still major barriers and challenges to establishing these kinds of community-led projects. Perhaps the most evident one is financial. While city officials might outwardly claim to support projects and even celebrate them, they rarely contribute financially to the realization and upkeep of these spaces. Several participants I spoke with mentioned the issue of financing projects and the lack of support from the City. Even when it comes to supporting non-profits working in UA, like La Maisonette des Parents, funds are increasingly being cut:

I've been asking them to work 35 hours per week per year so that I can design projects, but in return I just get more and more cuts ... It's as if [the City] doesn't want to keep the permanence of people in these neighborhoods to make them evolve ... I'm happy to do my job, but I'd also like to have the financing that comes with it, which isn't always the case.

We see here that there is a disconnect between the claims made by municipal officials and the actual support - or lack thereof - on the ground. While the City is lagging behind, however, support for UA is growing at the Borough level.

\section{The Push from Boroughs}

While gardens like the Mange-Trottoir, Beaux d'Écores, and the Jardin du Marché were established informally by groups of residents, many others initially emerged 
through partnerships with the municipality. Indeed, both the Jardin Pour Tous and CHAPEAU came out of the creation of 'citizen committees' at the borough-level. In the Hochelaga-Maisonneuve borough, for instance, there are five citizen committees working on various environmental projects, including the CHAPEAU, which is focused on UA. In practice, the committees are relatively independent from the institution, although they do receive some material support once in a while; for example, the borough will lend groups a space to hold meetings.

It is important to note that while the reappropriation of spaces for UA is an important issue in several boroughs, it is not a priority in others. In fact, some boroughs like Ville-Marie are more focused on other aspects of UA. In the Ville-Marie borough, located in the heart of downtown Montreal, the possibility for reappropriating spaces is very limited, given the virtual non-existence of vacant spaces. For one of the borough's councilors working on developing UA in this part of the city, other projects have more priority and relevance. Specifically, the borough is working to end food insecurity through the creation of a large greenhouse with the non-profit Carrefour Alimentaire Centre-Sud. Therefore, existing social, economic and spatial dynamics play an important role in determining whether or not community-led UA projects will emerge.

In spite of structural limitations, there is clearly a desire on the part of certain boroughs to encourage the creation of citizen UA projects. SODER is an organization that works for the Rosemont éco-quartier, and has recently started working on issues of citizen reappropriation. According to one of their employees, the City has fewer and fewer resources to take care of these residual or underused spaces, which is partly why the municipality is looking to citizens to take care of them. According to him, this has 
many positive aspects, especially in terms of opening these spaces up for people to use freely.

In the summer of 2015, the éco-quartier of Rosemont, in partnership with the SODER, implemented the program "Faites Comme Chez Vous" ("Make Yourselves at Home"). The main objective of this program is to encourage citizens to appropriate public, residual spaces for UA and other horticultural uses. As part of this program, the borough launched an online platform to facilitate citizen involvement. An interactive map allows people to select which spaces they would like to green and contribute to. The map offers various opportunities for greening spaces, including: watering a tree, planting in an alley, greening the median between the sidewalk and street, or joining an existing citizenproject. The structure of this program allows citizens to decide the level of commitment they want to put into transforming their neighborhood. It also gives them the option of participating individually, or to do so with neighbors in a more collective fashion. In August 2015, the borough sent out a crew to film and interview residents involved in UA projects. With the stories, photos, and videos gathered, the borough organized a small get-together at a community center in Rosemont at the end of August, to celebrate and showcase the spaces that citizens had transformed. The event, however, was not widely publicized to other community members, and so the people in attendance were mainly borough officials and those citizens whose projects were being showcased. Pictures of the projects that were selected were put up on display boards, and viewers had the opportunity to put stickers next to the ones they liked the most. The hope is that this project will grow in visibility and have a larger impact throughout the borough, not just the few that were selected for this publicity campaign. Therefore, the SODER team is 
already working to expand outreach efforts for Faites Comme Chez Vous. This includes putting lawn signs in those spaces that are available for transformation, as well as organizing more events for the community.

In practice, people do not necessarily go through the interactive platform before they start cultivating spaces. For example, a resident of the borough started the project Beaux D’Écores in the space below her apartment building in the spring of 2014, before the program had officially launched. Her garden later became registered under the banner of Faites Comme Chez Vous. Projects like these can be seen as a hybrid, blurring the limits between public and private spaces, insofar as they represent simultaneously an extension of people's private home spaces and the very public space of the street. The same happens in green alleys, where residents extend their living spaces to the alleyways behind their residence by planting vegetables or ornamental plants.

In this way, these projects appear to simultaneously benefit the city - by providing virtually free upkeep and beautification - as well as residents, giving them the ability to alter their living environment (McClintock 2014, Rosol 2012). As we will see shortly, however, these types of initiatives are not always as empowering as we might think. In this sense, it is important to situate these so-called innovative and participatory programs within the context of neoliberal urban development. Indeed, under Neoliberalism, previous functions undertaken by the government get rolled back, as new modes of governance are rolled out (Keil 2009). The devolution of previously public services onto non-profit organizations and individual citizens has, to a certain extent, come to be normalized. It is worth mentioning the commitment of Rosemont's mayor, François Croteau, to environmental issues and citizen-projects. Indeed, since his election 
in 2009, he has been one of the city's most vocal advocates for urban sustainable development. Furthermore, he is dedicated to citizen participation, and strives to integrate citizens' voices. For Croteau, participation means more than attending a meeting, and encompasses the use and transformation of urban space. Indeed, he believes that any citizen should be able to use residual public spaces, whether it is for gardening or another recreational purpose. This statement from summer 2014 clearly represents the vision he has for the future of the borough:

Ultimately, we want residents to appropriate public space and to exploit it wisely, without having to carry the weight of regulatory obstacles. It is a question of trust and good practices, because this space belongs to all of us. And urban agriculture appears to us as the ideal vector for this, because it touches upon what is most fundamental, that is food security and self-sufficiency.

Finally, the enthusiasm of Rosemont's municipal officials for a participatory model of sustainable urban development is not widely implemented throughout Montreal. Beyond variations in geography, there are other factors to take into consideration when considering community-led UA, especially when it comes to other stakeholders such as private landowners or public agencies.

\section{Working with Public Agencies}

When it comes to citizens reappropriating privatized spaces for UA, this kind of undertaking can look quite different. As a member of the group CHAPEAU suggests, navigating the process of reappropriation with certain stakeholders is fraught with difficulties. This became apparent when the CHAPEAU began to convert the terraces outside of the Joliette Metro station into a vegetable garden. The space in question is owned by the Société de Transport de Montréal (STM), the public agency in charge of 
mass transit in Montreal. The idea for this project emerged when residents noticed that the ornamental plants that had recently been planted on the terraces were being neglected and dying. This project involved challenging negotiations, largely because the STM repeatedly ignored citizens' request to transform the space. Finally, with the help of an elected official, the STM agreed to engage in a dialogue with CHAPEAU members. Recalling this process, one of the participants explains:

For the Metro Joliette project, [it was challenging] to be heard by the institution, to get the attention of the STM, we had to keep pushing. We had to go through the municipal councilor - who has his own connections - in order to reach the right person, the person who would accept to really hear what the project was about, not just receive a paper and pile it on their desk.

In the summer of 2015, after months of negotiation, the STM finally authorized the collective to plant vegetables on the terraces outside the Metro station. There were, however, restrictions as to what could be planted as well as regarding signage. Prior to putting up signs such as, "Help yourself" or "Food is free", the group is required to obtain the formal approval of the STM. Though it surely is not always the case, this example highlights the difficulties facing citizens when interacting with larger institutions, and just how difficult the reappropriation of certain spaces can be. Building a relationship of trust between different stakeholders, particularly with varying levels of power, can be an arduous task

These experiences have in turn affected how the CHAPEAU approaches citizen UA. Among members of the collective, there are often disagreements about how to go about new projects. According to one of the members: "All of the tensions that exist at the moment have more to do with people who would like to do interventions that are 
more underground, much less official." In this sense, some people are disillusioned about working in partnership with institutions and view guerilla interventions as an easier path to reappropriating space. For these participants with more anarchistic beliefs, it is obvious that asking permission to the City - or other institutions - will lessen possibilities for spatial reappropriation. Others in the collective still prefer to take a more formal approach, negotiating and communicating with institutions before planting. Ultimately, these ideological tensions have not impaired the group's functioning. The breadth of perspectives and political leanings might actually prove to be beneficial to the project as a whole, making it neither completely contestatory nor completely compliant with the City.

\section{Citizen-Projects Embedded Within an Organization}

There are many advantages to developing citizen-projects within a non-profit organization. In fact, an existing organizational structure offers a certain level of stability and reliable financial support. La Maisonette des Parents works closely with both private and public institutions. Having initiated seventeen collective gardens throughout the Petite Italie neighborhood, the garden manager reflects on the benefits of creating gardens in partnership with institutions, particularly with schools. Indeed, many of these gardens, while they are technically located on private land, are accessible from the street. This makes it possible for anyone walking by the school to freely harvest fruits and vegetables. Moreover, partnerships with institutions tend to safeguard the longevity of the project. About this, the garden manager suggests: "With institutions, it is more complex, it is more of a legal appropriation. But, at the same time, it can develop a permanence, whereas when you reappropriate public space, outside of institutions, it can be very 
temporary." Other practitioners similarly mentioned the benefits of working within existing organizational structures, as a way of keeping projects afloat. For Jean-Philippe Vermette, who works with the non-profit Carrefour Alimentaire Centre-Sud, "institutionalization makes it possible for initiatives to perpetuate, in the sense that a nonstructured citizen initiative will only last as long as actors are mobilized. If one day people are no longer mobilized, it dies."

While working with institutions can contribute to the preservation and continuation of these UA projects, institutionalization can also have some drawbacks, as the Petite Italie activist notes. He describes how oftentimes, there are tensions between organizations and citizens around the financing of projects, as organizations will not always distribute funds to help projects endure over time. Additionally, in some cases, UA projects become dependent on outside funders and have to comply with the goals and mission of those funders first. For a staff member at Bouffe-Action de Rosemont ("Rosemont Chow-Action"), an organization working on food security in the borough, this is problematic because it means that groups have less freedom to determine the focus of their work.

\section{Support from Non-Profit Organizations}

A growing number of non-profit organizations are dedicated to accompanying citizens through the process of establishing their respective projects. Alternatives partners with citizen-projects to teach horticultural skills, and to "promote knowledge sharing through conferences, workshops and community meetings" (Janvier and Doucet 2015, 4). Another non-profit, Lande (a "moor" or barren land), works specifically on helping 
citizens reappropriate vacant lots throughout the city. This organization was founded in Montreal in the spring of 2014. Largely inspired by the group 596 Acres in New York City, Lande works to identify vacant and underused lots (private and public) and subsequently helps groups of citizens navigate the process of reappropriating these spaces. As for 596 Acres, a critical tool for Lande has been the creation and management of an interactive map, which allows people to hover over their city and find vacant private or public spaces available for transformation. In Montreal, a surprising 25 square kilometers of land is left vacant, of which one-third is public and two-thirds are private; this represents about $11.7 \%$ of the city's total area (interview with founder of Lande).

As we have seen earlier, the process of reappropriation looks very different depending on who owns the land. Lande positions itself as the facilitator between groups of citizens and either city officials or private owners. But in both cases, the procedure starts the same way: after a certain number of people have expressed interest in a vacant lot through the interactive online map - usually around 10 people - Lande organizes a meeting to discuss the type of space everyone is interested in creating, as well as the next steps for contacting the owners of that land. Speaking to one of Lande's founders, it appears that this process is not easy, as private owners will not always respond positively. Furthermore, mobilizing citizens - who don't necessarily know each other to begin with - can be difficult. Oftentimes, people will click 'like' for a vacant lot on the interactive map, but a 'like' doesn't necessarily translate into a genuine interest in participating. So far, Lande has helped a few projects take off throughout Montreal, but it is a slow process since the organization is only volunteer-run. 
In April 2016, Lande published a report looking at the existing regulations surrounding vacant lots in Montreal, as well as identifying ways to facilitate the process of temporary reappropriation of urban spaces for its residents. This report is addressed to the City of Montreal - as opposed to the individual boroughs - with the hope of establishing comprehensive, city-wide policies around citizen reappropriation of vacant and underused spaces. Not surprisingly, the existing procedure is time-consuming and difficult to navigate: one must obtain a permit from the City and pay a fee, after which citizens must purchase insurance. According to the report, these administrative and financial hurdles have greatly limited the use of these spaces. Furthermore, the City might be hesitant to develop policies around temporary uses and reappropriation insofar as this could create tensions at the level of territory, as different groups might be competing to use the same land. Another issue for the City is the creation of additional responsibility and oversight regarding these temporary uses, something they often do not have the capacity for. One of Lande's three main recommendations to the City is to appoint someone to oversee the reappropriation of vacant land. Ultimately it waits to be seen how the City will respond to the report and whether or not they will take this growing movement of citizen reappropriation more seriously.

Finally, these examples reveal the complex relationship between community-led UA projects and municipal, non-profit or private actors. What can be seen across the board, however, is that once a certain level of trust is established between the two parties, it is easier for gardens to be recognized as legitimate uses of space. In fact, a good relationship with institutions can influence the longevity of the garden. As we have seen 
in some cases, these partnerships can be strenuous to certain groups, as power differentials dictate where the project is headed and what is or isn't allowed. 


\section{Section VI. Discussion:}

\section{The Production of Collective Spaces and Social Relationships}

The proliferation of citizen UA projects in Montreal points to a deeper transformation, both in terms of how urban space is being used and perceived, as well as regarding the emergence of collective social relations. Rather than one causing the other, I argue that these processes are fundamentally dialectical: different social relationships will shape space in a certain way, and space itself influences how people interact with one another.

\section{Transforming Residual Urban Spaces as Political Practice}

It is possible to view these citizen UA projects as part of a broader movement for Do It Yourself (DIY) or tactical - urbanism. Tactical urbanism is most often associated with urbanist and planner Mike Lydon of New York City, and puts forth the idea that anyone is capable of transforming urban spaces. There are many different motivations behind these spontaneous 'micro-spatial urban practices' (Iveson 2013), and while some purport a more subversive political message, others simply strive to make certain spaces more functional or aesthetically pleasing. Reappropriating spaces through DIY or tactical urbanism carries a powerful message insofar as it makes visible an alternative urbanism, one that is not determined by experts and planners but rather by the city's everyday users. From a Lefebvrian perspective, tactical urbanism embodies the Right to the City, the right for urban inhabitants to shape the city into a creative 'oeuvre.' Yet the transient character of some DIY initiatives calls into question long-term changes to urban 
environments (Finn 2014, Iveson 2013). For one of the founders of Lande, these projects are indeed meant to be impermanent: "We aim for something temporary, we like to say transitory, because, of course, as an organization that wants to do tactical urbanism, we don't want to constrain development, whether it is on public or private land." This statement suggests that DIY initiatives - such as citizen UA projects - should not interfere with the dominant spatial order, and that they should instead serve as a sort of placeholder for future neoliberal urban development. For Iveson (2013), the absence of confrontation and compliance with the existing spatial (and social) order undermines the political reach of any DIY project. He claims:

DIY practices of appropriating urban space and infrastructure for alternative purposes do not necessarily constitute a democratic urban politics that will give birth to a new city. Certainly, such practices have the potential to establish democratic rights to the city. But for this potential to be realized, new democratic forms of authority in the city must be asserted through the formation and action of new political subjects. (Emphasis added)

Looking back at Lande, it becomes apparent that by not wanting to interfere with development, the reappropriation of spaces by and for citizens is a secondary claim to urban space. This 'authorized reappropriation', while it does hold potential to foster new political subjects, appears in fact to align with (or at least not interfere with) economic and political interests at the top. As the new policies of the Rosemont borough demonstrate, citizen UA projects that started out as insurgent and illegal appropriations of space, are being folded into a new 'progressive urbanism' that encourages people to take an active role in shaping their environment without truly destabilizing the status quo.

For some critical scholars, spatial interventions like citizen-led UA, although being led by groups of citizens, mask a tenet of neoliberal urban governance. In her work 
on community gardens in Berlin, Marit Rosol explains that the participation of community members in managing gardens can be understood as "a form of outsourcing of former local state responsibilities for public services and urban infrastructure" (Rosol 2012, 239). This "governance through community" (Rosol 2012) disproportionately responsibilizes citizens to take on tasks previously assigned to state entities. This devolution of responsibilities is something that one of the founders of the Jardin du Marché has noticed in Montreal. Reflecting on the Rosemont borough's recent public support for citizen reappropriation of spaces, he claims:

For me personally, I find it great, but like I said, it's also a way of deresponsablizing themselves [the Borough] regarding the creation of projects in underused public spaces. It means that they are conscious that these spaces are under-utilized, abandoned, or even dangerous. And they will say: 'Citizens, take the lead and start a project,' but often it ends up being like it is here. We see that there is a great potential, but we also see that there is clearly a lack of means and resources.

This comment reflects what several UA practitioners have expressed about the overall lack of municipal support for UA projects. While some city officials might outwardly claim to support projects and even celebrate them, they seldom contribute financially to the production and upkeep of these spaces.

\section{Fostering Collective Social Relations}

In spite of the tendency to view these projects as "regressive, neoliberal enterprises, simply filling the gaps of state retrenchment" (Wekerle and Classens 2015, 1176), it is still possible to find elements of a radical democratic politics within them. Drawing from Purcell's work on radical democracy, we can discern similarities between the reappropriation of one's individual (or constituent) power and the reappropriation of 
urban spaces for UA. For one participants at the Jardin Pour Tous, this aspect of community-led UA is what first jumped out to him: "My first experience with UA has been: the citizen is capable of doing something." This sense of empowerment is something many participants brought up (see Section IV). Projects like these thus become critical spaces for people to gain a sense of agency, emphasizing the idea that anyone can contribute something to the space. One of the main goals at La Maisonette des Parents, is to foster autonomisation (autonomy, self-reliance) in people, particularly those affected by food insecurity. This does not imply that people will achieve total self-reliance when it comes to food, but rather that they will acquire tools and strategies when faced with difficult situations.

These UA projects, then, are about much more than food production; they are also about the development of self and collective expression through space. In this sense, a lot of citizen-projects are incorporating art and various forms of creative expression. These range from painting raised beds, to building benches, bringing and taking books from free libraries, or displaying poems and quotes. In some cases, this artistic dimension can be a vehicle for politicizing spaces. For instance, throughout the collective gardens at $\mathrm{La}$ Maisonette des Parents, one can find quotes by the political humorist Sol, around themes of social justice. This sign displayed at the Jardin Pour Tous (Figure 5), encourages people to contribute, no matter their skills or background. The second paragraph reads: "Amateur gardeners, DIY enthusiasts, dreamers, artists, photographers, are welcome in the garden, and all can contribute to the creation of this space." 


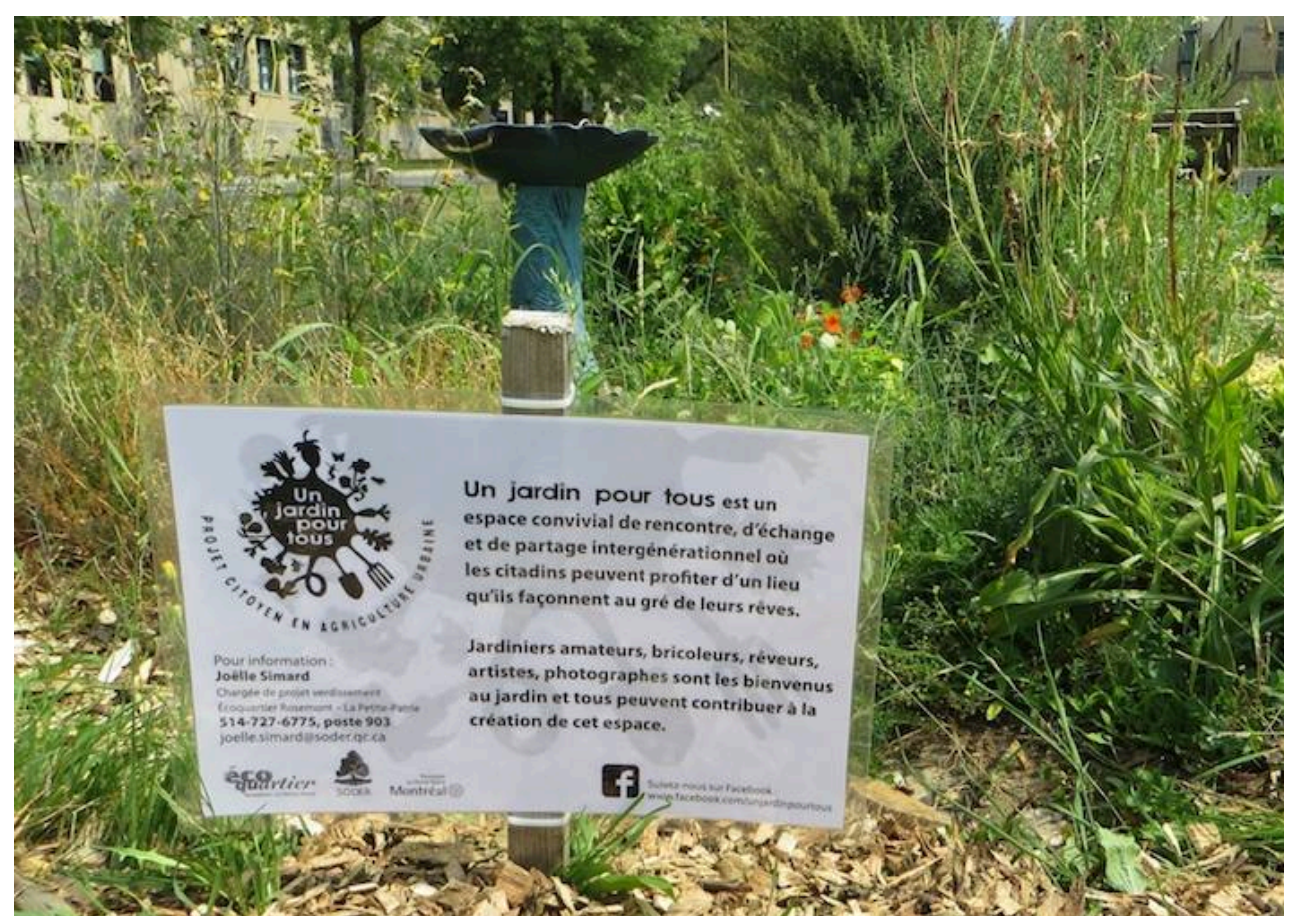

Figure 5. Invitation to participate at the Jardin Pour Tous

While the reappropriation of one's own power is clearly an individual project, it is also fundamentally a collective endeavor. According to Gibson-Graham (cited in Levkoe 2011, 692), "this cultivation of the self offers a potential to enable participation in creative and innovative forms of collective action through (re)creating individuals as communal subjects." The collective nature of these citizen-projects suggests that spaces and social relationships are fundamentally shifting. Many scholars have already suggested that the emergence of commons and collective practices represent a significant turning point in how city dwellers conceive of - and interact within - these spaces (Eizenberg 2012, Tornaghi 2014). Whereas this relationship is often characterized as passive, there is now an active and conscious process of material transformation at work. This transformation bears resemblance to Lefebvre's concept of 'collective autogestion', 
as people learn new ways of managing themselves in common. According to Eizenberg (2011, 774-775),

the collective production of space propels the development of the socio-spatial gaze of residents that amounts to a conceptual framework regarding space and its users. The space of the commons allows for an alternative experience of the everyday life, which clashes with the dominant experience. As a result, a new consciousness is developed.

These changes involve the conscious decision of moving away from atomized and individualistic ways of living, to instead collaborating and making people invested not only in their own wellbeing but also in the wellbeing of their community. The example of the children realizing that taking a tomato doesn't equate with stealing, shows just how ingrained ideas of individual property are in our society. Furthermore, for such a consciousness to emerge, people need to feel "called out to" or "hailed" (interpelés). This process is both internal and external, and will depend on myriad factors related to one's positionality and relationship to others.

However, the process of working collaboratively is not easy or straightforward. As McIvor and Hale (2015) explain, "collective agency does not imply frictionless harmony or easy equality. Urban agriculture practitioners must be sensitive to differences in perspectives, interest, and power." In this sense, groups are learning to deal with conflict and disagreement. Citizen-projects in Montreal often struggle with power imbalances, as well as differences in opinions and perspectives. For one of the members of the Jardin Pour Tous, openly engaging with these issues has played a critical role in the development of the garden: "For a project to really bring people together, you need a lot of openness towards divergence of opinions, divergence of perspectives, so that everyone can find their place [in the group]." Oftentimes, this is where non-profit 
organizations such as Alternatives will jump in. Through educational workshops around consensus, non-violent communication and other themes related to collective decisionmaking, people develop a better understanding of collective work as well as of their own place within the group. At La Maisonette des Parents, much of the education in the gardens focuses on this: "Teaching direct democracy to kids and young adults ... deciding what to plant, who does what and how we get organized, the way we communicate, all of these decisions are made by citizens."

It is important to mention that while these groups advocate inclusivity and the ability for all to participate, the demographics of participants point to some exclusion, however unintended. Through my interviews and participant observation, it is clear that many participants are white, educated, and eco-conscious. Despite the projects being highly intergenerational, these other demographics suggest that only a small subset of the population is involved in citizen-projects. This kind of homogeneity has a direct impact on the spaces created, as it forecloses other possibilities and uses of these spaces. Furthermore, it forecloses participation by other groups, and the ability of more marginalized groups to create their own spaces. ${ }^{7}$ This kind of homogeneity has a direct impact on the spaces created, as it forecloses other possibilities and uses of space

Ultimately, these citizen-projects demonstrate that the reappropriation of one's power is fundamentally a spatial practice (as opposed to an intellectual one, for example). As Swyngedouw (2011) and Davidson and Iveson (2014) remind us, a

\footnotetext{
${ }^{7}$ For example, people of color may feel alienated by the high make-up of white bodies in these spaces (see Slocum 2007). More specific to Montreal, minority allophone populations (speaking English) may feel left out of these predominantly French-speaking projects.
} 
democratic politics can only fully take shape within geographical space. This is not to say that a democratic politics can easily be established in any given space, but rather that the latter is a necessary tool for moving towards such a politics. Purcell's concept of the horizon of radical democracy is useful in understanding how these UA initiatives are materializing possibilities for social change. Following Lefebvre, the re-appropriation and transformation of urban spaces by citizens is an emancipatory act: "The right to the city (...) signifies the constitution or reconstitution of a spatial-temporal unit, of a gathering together instead of a fragmentation" (Lefebvre 1996, 195). For Lefebvre, the right to the city is first and foremost a right to create urban space, a right to what is possible.

Turning to Rancière's understanding of the political as a moment of disruption of the existing social (and spatial) order, my findings suggest that citizen-led UA projects are only minimally disruptive. Indeed, projects do not fundamentally challenge normative land use practices and the capitalist organization of space. As demonstrated by the Rosemont-La-Petite-Patrie borough, citizen-projects can very easily be integrated within municipal programs. This reminds us of Rancière's warning that 'the political' always ends up being folded back into 'the police.' This is not meant to equate all citizen-UA projects as fundamentally apolitical, but rather goes to show that the police is able to harness those elements that benefit it, and quell those that undermine it. Ultimately, Rancière's partition of the sensible is not fundamentally challenged by these spaces. Nonetheless, within these spaces, emphasis is placed on equality and the fostering of collective identities. So while we might get a glimpse of Rancière's re-inscriptions of equality in these particular spaces, these processes remain disconnected from the existing 
social order, and from the rest of the city. Furthermore, the somewhat insular composition of participants (white, eco-conscious, middle class) prompts the question of pre-existing homogeneity and the exclusion of other populations.

It is important then, not to equate these practices and the transformation of spaces for UA, with a radical democratic politics. In fact, space is not imbued with an a priori political or transformational quality. In this regard, Stehlin and Tarr (2016) caution against a purely performative progressive urbanism, which disproportionately focuses on changing urban form, and does not fundamentally destabilize the social (and spatial) order. By prioritizing localized interventions in space, progressive urbanism risks falling into the local trap (Purcell 2006), which posits that the local scale is inherently 'good.' This assumption is problematic insofar as it bars social and political changes from occurring at other scales. This view assumes that the local is the most legitimate and conducive scale for social change. Stehlin and Tarr (2016) go on to explain the lacuna of such a politics:

The 'good sense' of progressive urbanism then dictates that the proper redress is to birth a new city, yard-by-yard, block-by-block, and street-by-street from below. This epistemological shift elides questions of power, particularly the power to control wealth, and makes the kinds of politics we discuss here [i.e., tactical urbanism] distinct from the types of grassroots politics that build broad-based collective power. (Stehlin and Tarr 2016,4)

This is not to say that micro-spatial transformations cannot be political spaces altogether, but rather that when they are placed under the umbrella of progressive or sustainable urbanism, they risk being de-politicized. The move towards institutionalizing citizen reappropriation of spaces in Rosemont-La Petite-Patrie through programs like 
Faites Comme Chez Vous exhibits some of these tensions. On the one hand, recognition and avid support from municipal officials serves to legitimize these practices, as has been the case with projets like the Mange-Trottoir and the Jardin Pour Tous. This can help projects develop a permanence that might otherwise be lost outside of institutions. On the other hand, institutionalization risks de-politicizing and standardizing these initiatives. While municipal programs like Faites Comme Chez Vous strive to empower citizens, it is useful to think about why this kind of support is emerging. In many ways, these initiatives are improving the image and even competitiveness of their borough. As Duchemin asserts, in boroughs like Rosemont, "when you green a vacant space without asking for permission, the mayor of the borough or a municipal official will show up right away to tap you on the back and congratulate you for your initiative" (quoted in Deschênes 2016). The risk then, which the manager of La Maisonette des Parents clearly perceives, is that campaigns like Faites Comme Chez Vous are stripping gardening of its social and political dimensions, and focusing disproportionately on the greening aspect. Indeed, the promotion of citizen UA - and other greening initiatives - as a way of making the City more livable and sustainable, rests on the problematic assumption that this is the most desirable way of using these residual spaces. ${ }^{8}$

\footnotetext{
${ }^{8}$ Moreover, as Swyngedouw (2010) and Classens (2015) point out, there is a risk of not only depoliticizing social practices, but also of portraying nature and ecological processes as unproblematic and static phenomena. Saying that gardens are inherently 'good' is reductive of what actually happens in nature, the biological processes that give way to seeds, plants, and so forth. From this perspective, the political potential of UA does not reside simply in social action, but also comes from the "inherently radical potential of plants" Classens $(2015,236)$. Classens further explains $(2015,236)$ : "Plants self-reproduce for free. They are radically democratic in that they can be grown by anyone, almost anywhere. They allow one to disentangle themselves from the corporate food system. Plants resist being branded." In this sense, the political potential of UA is not simply a result of social practices, but should instead be conceptualized as residing within a socio-ecological practice. This is why the reappropriation of space for $U A$ is so different, for example, than the reappropriation of space for a built structure. As a participant of UA in Montreal explains: "I think the act of planting a seed in terms of reappropriation, is very strong, because you see it
} 


\section{Section VII. Conclusion}

Ultimately, this study of citizen-led UA projects in Montreal provides some insights into the complex politics of spatial reappropriation. As we have observed throughout this paper, establishing and maintaining informal collective gardens presents numerous challenges: on the one hand, there are external challenges related to property ownership and to the bureaucracy and regulations governing land tenure. On the other hand, internal challenges emerge within groups, as individuals come together with differences in perspectives and power. Yet, in spite of these challenges there appears to be a strong desire to keep growing food in vacant and residual spaces, and to extend these practices to new parts of the city.

Beyond the act of growing food, these initiatives have demonstrated how new collective identities and relationships are being cultivated within these spaces. In this sense, the collective reappropriation of residual urban space manifests some elements of a democratic urban politics, as people exert agency and develop what Lefebvre calls 'collective autogestion.' This is not to say that these UA projects are political in Rancière's sense of the term. Neither are these projects entirely self-reliant; as we have observed, their continued existence often relies on other actors from non-profit organizations, to municipal officials, schools, and private donors. The case of Rosemont La-Petite-Patrie demonstrates just how these practices are becoming institutionalized and integrated within a broader framework of sustainable and participatory urban governance.

The discourses and practices surrounding these changes suggest that these practices risk

grow with time, it changes... But say a wooden structure made out of wood pallets, that's also fun but I know that to have something that's alive, that it creates something strong." 
being stripped of their political dimension, insofar as they are portrayed as inherently 'good' for people and the environment. Following Iveson (2013) and Stehlin and Tarr (2016), these citizen-projects can contribute to a democratic urban politics, so long as they are able to make broader social and political claims, beyond the ultra-local scale of their projects and beyond the people who are directly involved. 


\section{References}

Blomley, N. 2003. Unsettling the City: Urban Land and the Politics of Property. New York: Routledge.

Classens, M. 2014. The nature of urban gardens: toward a political ecology of urban agriculture. Agriculture and Human Values 32 (2):229-239.

Cohen, N., and K. Reynolds. 2014. Urban Agriculture Policy Making in New York's "New Political Spaces" Strategizing for a Participatory and Representative System. Journal of Planning Education and Research 34 (2):221-234.

Corcoran, M. P., and P. C. Kettle. 2015. Urban agriculture, civil interfaces and moving beyond difference: the experiences of plot holders in Dublin and Belfast. Local Environment 20 (10):1215-1230.

Davidson, M. 2009. Social sustainability: a potential for politics? Local Environment 14 (7):607-619.

Davidson, M., and K. Iveson. 2014. Occupations, mediations, subjectifications: fabricating politics. Space and Polity 18 (2):137-152.

Direction des Grands Parcs et du Verdissement de la Ville de Montréal. 2012. État de l'Agriculture Urbaine à Montréal.

Duchemin, É. 2012. La participation communautaire pour définir la ville viable : questionnement sur l'appropriation de l'espace urbain. VertigO - la revue électronique en sciences de l'environnement (Volume 11 Numéro 3). https://vertigo.revues.org/11597 (last accessed 23 October 2016).

—. 2013. Agriculture urbaine: aménager et nourrir la ville. VertigO.

Duchemin, E., F. Wegmuller, and A.-M. Legault. 2008. Urban agriculture: multidimensional tools for social development in poor neighbourhoods. Field Actions Science Reports. The journal of field actions (Vol. 1). https://factsreports.revues.org/113?lang=fr (last accessed 22 October 2016).

Eizenberg, E. 2012. Actually Existing Commons: Three Moments of Space of Community Gardens in New York City. Antipode 44 (3):764-782.

- 2013. From the Ground Up: Community Gardens in New York City and the Politics of Spatial Transformation New edition edition. Farnham, Surrey, England; Burlington, VT: Routledge.

Hardt, M., and A. Negri. 2001. Empire. Cambridge, Mass.: Harvard University Press. Holmgren, D. 2010. 12 Principles of Permaculture. Reach and Teach's Just Lists. 
https://justlists.wordpress.com/2010/01/14/principles-of-permaculture/ (last accessed 22 October 2016).

Incredible Edible Todmorden | The Future Of Local Food In Todmorden. https://www.incredible-edible-todmorden.co.uk/ (last accessed 23 October 2016).

Iveson, K. 2013. Cities within the City: Do-It-Yourself Urbanism and the Right to the City. International Journal of Urban and Regional Research 37 (3):941-956.

Janvier, G., and J. Doucet. 2015. Feeding Citizenship: strategies for accessing and transforming spaces. Cities and the Environment (CATE) 8 (2).

http://digitalcommons.lmu.edu/cate/vol8/iss $2 / 21$.

Keil, R. 2009. The urban politics of roll-with-it neoliberalization. City: analysis of urban trends, culture, theory, policy, action 13 (2-1):230-245.

Lefebvre, H. 1965. Writings on Cities by Henri Lefebvre. Wiley-Blackwell.

Le fruit social de l'agriculture urbaine. http://montrealcampus.ca/2016/08/le-fruit-socialde-lagriculture-urbaine/ (last accessed 22 October 2016).

Levkoe, C. Z. 2011. Towards a transformative food politics. Local Environment 16 (7):687-705.

Masse, B. and Beaudry, M. 2008. Les jardins collectifs et l'agriculture urbaine, formes de renouvellement de la solidarité urbaine. Collectif d'études sur les pratiques solidaires.

McClintock, N. 2014. Radical, reformist, and garden-variety neoliberal: coming to terms with urban agriculture's contradictions. Local Environment 19 (2):147-171.

McIvor, D. W., and J. Hale. 2015. Urban agriculture and the prospects for deep democracy. Agriculture and Human Values :1-15.

Merrifield, A. 2006. Henri Lefebvre: A Critical Introduction 1 edition. New York: Routledge.

Notre bilan de mandat (1 de 3) - François William Croteau.

http://www.francoiscroteau.com/2013/08/26/notre-bilan-de-mandat-1-de-3/ (last accessed 25 October 2016).

Office de Consultation Publique. 2012. État de l'Agriculture Urbaine à Montréal: Rapport de Consultation Publique.

Perkins, H. A. 2009. Out from the (Green) shadow? Neoliberal hegemony through the market logic of shared urban environmental governance. Political Geography 28 (7):395-405. 
Plan de Développement Durable 2010-2015. Ville de Montréal.

Provost, A.-M. Jardins communautaires: Des listes d'attente débordent. Le Journal de Montréal. http://www.journaldemontreal.com/2015/05/29/jardins-communautaires-deslistes-dattente-debordent (last accessed 21 October 2016).

Purcell, M. 2006. Urban Democracy and the Local Trap. Urban Studies 43 (11):19211941.

2013. The Down-Deep Delight of Democracy 1 edition. Chichester, West Sussex: Wiley-Blackwell.

Purcell, M., and S. K. Tyman. 2015. Cultivating food as a right to the city. Local Environment 20 (10):1132-1147.

Ranciere, J. 2011. Haine De La Democratie FABRIQUE edition. Paris: La Fabrique.

Reynolds, R. 2008. On Guerrilla Gardening: A Handbook for Gardening Without Boundaries First Edition edition. New York: Bloomsbury USA.

Rosol, M. 2012. Community Volunteering as Neoliberal Strategy? Green Space Production in Berlin. Antipode 44 (1):239-257.

Saint-Hilaire-Gravel, P. 2013. "Les jardins communautaires montréalais: une histoire riche d'apprentissage" in Agriculture urbaine: aménager et nourrir la ville. Ed. Éric Duchemin. VertigO.

Senecal, G. 2002. Montréal's Eco-quartier environmental program: local action and municipal management. Environmental Management 30 (1):46-58.

Slocum, R. 2007. Whiteness, space and alternative food practice. Geoforum 38 (3):520533.

Spiegel, J. B. 2015. Rêve Général Illimité? The Role of Creative Protest in Transforming the Dynamics of Space and Time During the 2012 Quebec Student Strike. Antipode 47 (3):770-791.

Stehlin, J. G., and A. R. Tarr. 2016. Think regionally, act locally?: gardening, cycling, and the horizon of urban spatial politics. Urban Geography 0 (0):1-23.

Stiegman, M. 2004. Au coeur de notre quartier: un guide pratique pour le démarrage et l'animation d'un jardin collectif. Action Communiterre.

Swyngedouw, E. 2010. Impossible Sustainability and the Post-political Condition. In Making Strategies in Spatial Planning, Urban and Landscape Perspectives., eds. M. Cerreta, G. Concilio, and V. Monno, 185-205. Springer Netherlands http://link.springer.com/chapter/10.1007/978-90-481-3106-8_11 (last accessed 22 
October 2016).

- 2014. Where is the political? Insurgent mobilisations and the incipient "return of the political." Space and Polity 18 (2):122-136.

Tornaghi, C. 2014. Critical geography of urban agriculture. Progress in Human Geography:0309132513512542.

Tornaghi, C., and B. V. Dyck. 2015. Research-informed gardening activism: steering the public food and land agenda. Local Environment 20 (10):1247-1264.

Tracey, D. 2007. Guerrilla Gardening: A Manualfesto. Gabriola Island, BC: New Society Publishers.

Victory Gardens at a Glance. http://www.nationalww2museum.org/learn/education/forstudents/ww2-history/at-a-glance/victory-gardens.html (last accessed 22 October 2016).

Wegmuller, F., and E. Duchemin. 2010. Multifonctionnalité de l'agriculture urbaine à Montréal : étude des discours au sein du programme des jardins communautaires.

VertigO - la revue électronique en sciences de l'environnement (Volume 10 numéro 2). https://vertigo.revues.org/10445 (last accessed 19 March 2016).

Wekerle, G. R., and M. Classens. 2015. Food production in the city: (re)negotiating land, food and property. Local Environment 20 (10):1175-1193. 
Appendix A: Interview Guide for UA practitioners (August 2015)

\section{Contexte}

- Depuis quand participez-vous?

- Qu'est ce qui vous a poussé à vous impliquer dans ce projet?

- Quand est-ce que le projet a été créé ?

- Avez-vous participé à des projets similaires par le passé ? (autres mouvements sociaux)

- Aviez-vous de l'expérience en jardinage ?

\section{Fonctionnement}

- Y'a-t-il une structure en place pour le fonctionnement du projet ?

- Comment les gens s'impliquent-ils et restent-ils impliqué ? (via internet, etc.)

- Avez-vous fait du recrutement? (ou les gens sont-ils venus d'eux-mêmes ?)

- Y'a-t-il des stratégies qui marchent plus que d'autres (ce que Gaëlle Janvier disait sur les réunions toutes les 2-3 semaines)

- Quelles sont tes responsabilités principales?

- Comment les décisions par rapport au jardin sont-elles prises?

- Y'a-t-il parfois des conflits entre membres ?

- Comment gérez-vous ces conflits?

- Quelles stratégies avez-vous pour intégrer les idées parfois opposés des membres?

- Niveau financement, comment cela marche-t-il?

- Quels sont les avantages d'une organisation horizontale/non-hiérarchique ?

\section{Personnes}

- Combien de personnes participent?

- Qui participe ? (voisins, amis, autres) Comment faire pour que les gens restent impliqués dans le projet ?

- Ce projet a-t-il permis une plus grande cohésion entre habitants du quartier ?

- Qui bénéficie de ce genre projet?

\section{Rôle de l'AU}

- Quel potentiel voyez-vous dans la réappropriation d'espaces publiques pour l'AU ? (ou : Pensez-vous qu'il est nécessaire pour l'avenir de l'AU d'utiliser des espaces comme les rues par exemple?)

- En quoi est-ce différent des jardins collectifs ou communautaires?

- Quels bénéfices émergent de ce projet ? (à part bien sur les légumes)?

- Vois-tu la ville comme alliée dans ce genre de projets ? (limitations versus benefits)

- À votre avis, qu'est-ce qui explique le renouveau d'intérêt envers l'AU ?

- Est-ce que vous pensez qu'il y a un lien entre les mouvements sociaux des années 1960 au Québec avec l'AU à Montréal ? 
Appendix B: Interview Guide for Municipal Officials (April 2016)

\section{Point de Vue}

- Comment vois-tu le renouveau d'intérêt pour l'AU à MTL? Pourquoi cet engouement pour l'AU?

- A la fois guérilla gardening et appropriation plus légale ? Quels sont les avantages de l'un et de l'autre?

- Quels bénéfices ou inconvénients peuvent venir de l'institutionnalisation de ces initiatives citoyennes? Peut-etre que ça permet d'établir une permanence dans l'espace?

- Quelles barrières y'a-t-il qui empêchent un développement de ce genre de projets?

\section{Pourquoi l'AU ?}

- Est-ce que vous pensez que ce genre de projets peut augmenter la participation citoyenne? société plus démocratique?

- Quels bénéfices émergent de ce projet ? (à part bien sur les légumes)?

- Vois-tu la ville comme alliée dans ce genre de projets ? (limitations versus benefits)

- Est-ce que les jardins collectifs ouverts à tous peuvent vraiment faciliter l'accès aux aliments? (autres barrières : savoir cultiver etc)

\section{Implication}

- Peux-tu un peu parler du Carrefour Alimentaire Centre Sud ?

- Comment les gens s'impliquent-ils et restent-ils impliqué ? (via internet, etc.)

- Avez-vous fait du recrutement ? (ou les gens sont-ils venus d'eux-mêmes ?)

- Y'a-t-il des stratégies qui marchent plus que d'autres pour faire que les gens restent impliqués ? (ce que Gaëlle Janvier disait sur les réunions toutes les 2-3 semaines)

- Qui participe ?

Comment faire pour que les gens restent impliqués dans le projet ?

- Ce projet a-t-il permis une plus grande cohésion entre habitants du quartier?

\section{Responsabilités/Conflits}

- Comment les responsabilités sont-elles distribuées?

- Comment les décisions sont-elles prises?

- Y'a-t-il parfois des conflits entre membres ou partenaires ?

- Comment les conflits sont-ils gérés ?

- D'où vient le financement ? 
Appendix C: Additional Interviews from MTL-PDX Field Course

\begin{tabular}{ll}
\hline Name & UA Organization (Borough) \\
\hline Julie Poirier & Bouffe-Action de Rosemont (Rosemont-La Petite-Patrie) \\
Carlo Primiani & Santropol Roulant (Plateau Mont-Royal) \\
& \\
\hline
\end{tabular}


Appendix D: Examples of Codes Employed to Analyze interview Data

\begin{tabular}{|c|c|c|}
\hline $\begin{array}{c}\text { RQ 1: } \\
\text { reappropriated? }\end{array}$ & $\begin{array}{c}\text { RQ 2: } \\
\text { How are spaces being } \\
\text { reappropriated? }\end{array}$ & $\begin{array}{c}\text { RQ 3: } \\
\text { UA as means of } \\
\text { producing alternative } \\
\text { spaces and social } \\
\text { relations }\end{array}$ \\
\hline Environmental mission & Citizens taking initiative & Empowerment \\
\hline Food insecurity & Positive relation with \\
institutions & Community-building \\
\hline Food is Free & Negative relation with \\
institutions & $\begin{array}{c}\text { Collective decision- } \\
\text { making }\end{array}$ \\
\hline Education & Challenges/Barriers & Right to the City \\
\hline Alternatives to existing & Strategies/Tactics & Equality \\
\hline UA sites & & \\
\hline
\end{tabular}

